\title{
Increased Abundance of Plasmacytoid Dendritic Cells and Interferon-Alpha Induces Plasma Cell Differentiation in Patients of IgA Nephropathy
}

\author{
Nuoyan Zheng, ${ }^{1,2}$ Bing Wang, ${ }^{3}$ Jinjin Fan, ${ }^{2}$ Ning Luo, ${ }^{2}$ Qingyu Kong, ${ }^{2}$ Hongjian Ye, \\ Jiqin Zhang, ${ }^{1}$ Hongyan Ming, ${ }^{3}$ and Xueqing $\mathrm{Yu}^{2}$ \\ ${ }^{1}$ Translational Medical Center, The First Affiliated Hospital of Sun Yat-sen University, Guangzhou, China \\ ${ }^{2}$ Department of Nephrology, The First Affiliated Hospital of Sun Yat-sen University, Guangzhou, China \\ ${ }^{3}$ International Travel Health Care Center, Entry-Exit Inspection and Quarantine Bureau, Guangzhou, Guangdong Province, China
}

Correspondence should be addressed to Nuoyan Zheng; zhnuoy@mail.sysu.edu.cn and Xueqing Yu; yuxq@mail.sysu.edu.cn

Received 27 May 2017; Revised 30 August 2017; Accepted 24 September 2017; Published 18 December 2017

Academic Editor: Anshu Agrawal

Copyright () 2017 Nuoyan Zheng et al. This is an open access article distributed under the Creative Commons Attribution License, which permits unrestricted use, distribution, and reproduction in any medium, provided the original work is properly cited.

\begin{abstract}
The roles of pDC and IFN- $\alpha$ have not been well defined in IgA nephropathy (IgAN). In this study, we investigated the abundance of pDCs and IFN- $\alpha$ in IgAN patients and the response of peripheral blood mononuclear cells (PBMCs) after stimulation of the pDC-preferred TLR9 ligand CpG2216. The effects of IFN- $\alpha$ on plasma cell differentiation and leukocyte migration were also investigated. Here, we found that the percentages of pDCs were increased in PBMCs of IgAN patients, than in those of healthy controls. Plasma levels of IFN- $\alpha$ proteins and abundance of plasma cells were higher in IgAN patients than in healthy donors. Plasma IFN- $\alpha$ levels were positively associated with proteinuria, renal IgM deposition, and renal tubular atrophy/interstitial fibrosis grade in IgAN patients. Ex vivo activation of TLR9 on pDCs resulted in increased IFN- $\alpha$ production and enhanced plasma cell differentiation in IgAN patients as compared with healthy donors. IFN- $\alpha$ treatment led to increased plasma cell differentiation in vitro. IFN- $\alpha$ also significantly promoted expression of chemokines IP-10 and MCP-1 in human mesangial cells, which subsequently facilitated the transendothelial migration of human CD4 ${ }^{+}$ and $\mathrm{CD}_{1}{ }^{+}$cells. In conclusion, $\mathrm{pDC}$ and its secreted cytokine IFN- $\alpha$ may play important roles in pathological changes of IgA nephropathy.
\end{abstract}

\section{Introduction}

IgA nephropathy (IgAN) was the most common form of primary glomerulonephritis worldwide, and it is well accepted that the interaction between genetic, epigenetic, and environmental factors may synergistically contribute to the pathogenesis of IgAN [1-4]. One of the environmentalrelated factors, infection of pathogens, has been well acknowledged for the pathogenesis of IgAN; about 30\% of IgAN patients suffered from disease onset and/or progression after upper respiratory infection or gastrointestinal infection $[5,6]$. Bacterial and viral antigens (such as Staphylococcus aureus, Haemophilus parainfluenzae, Epstein-Barr virus, and retroviruses) have been detected in the renal specimens of IgAN patients [6-8]. In defending against these foreign pathogens, toll-like receptor (TLRs) family members are critical by triggering strong innate and adaptive immunity in the host [9]. Upon recognition of pathogen-associated molecular patterns, TLRs recruit adaptor molecules such as MyD88 and TRIF to initiate downstream signaling events which leads to the secretion of inflammatory cytokines, type I IFN, chemokines, and so forth and subsequently causes a serial of inflammatory response including recruitment of neutrophils, activation of macrophages, maturation 
of dendritic cells, and induced expression of serials of IFNstimulated genes for killing infected pathogens [10, 11]. Although TLRs are very effective for fighting pathogens, they may also act as a double-blade sword since enduring activation of TLRs may cause uncontrolled inflammatory responses and tissue damages [12-14]. In addition to recognizing exogenous ligands, TLRs may also recognize endogenous ligands including self-proteins and endogenous nucleic acids then elicit autoimmune disease as in rheumatoid arthritis and systemic lupus erythematosus [15]. The important roles of TLR4 and TLR9 in IgAN have been studied by several groups, pointing out that their expression was associated with disease severity and even the pathogenesis of IgAN [16-20], but the underlying mechanism of how TLRs led to the pathogenesis of $\operatorname{IgA}$ nephropathy is not fully elucidated.

Plasmacytoid dendritic cells (pDCs) are relatively new in the category of immune cell types, which were first fully characterized in 1999. Given the fact that $\mathrm{pDCs}$ are very rare, accounting for $0.3-0.5 \%$ of the human peripheral blood cells, the biology and function of pDCs in diseases are incompletely understood [21]. The immunophenotype markers of pDCs in the blood have been reported in several studies and characterized as $\operatorname{Lin}(\mathrm{CD} 3 / 14 / 56 / 19 / 20 / 16)^{-} \mathrm{CD} 123^{\text {high }}$

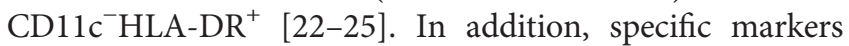
BDCA-2 and BDCA-4 are also exclusively expressed on pDCs which reside in blood and bone marrow [26]. The primary and unique function of $\mathrm{pDCs}$ is the secretion of type I interferon (IFN- $\alpha / \beta)$ in response to virus and/or virus-derived nucleic acids and/or apoptotic cell-derived nucleic acids [27-29]. Studies revealed that TLRs expression pattern in pDCs is restricted to TLR7 and TLR9 [30] and their activation leads to substantial production of IFN- $\alpha$ [21]. The endosome-located TLR7 and TLR9 are, respectively, responsible for sensing single-stranded RNA and unmethylated $5^{\prime}$-cytosine-phosphate-guanine- $3^{\prime}$ (CpG) DNA motif, later eliciting the production of large amount of IFN- $\alpha$ in pDCs which can be up to 1000 -fold of other cell types [31]. In fact, IFN- $\alpha$ production in response to bacteria CpG motif challenge in vivo is exclusively mediated by pDCs, which pass through the TLR9/MyD88/ IRF7 signaling pathway $[32,33]$. There are three types of CpG DNA (CpG-A, CpG-B, and CpG-C) targeting different cell populations and result in different downstream events. Type CpG-A is very potent in provoking type I interferon production in pDCs but very weak in stimulating $\mathrm{B}$ cell response, while it enhances the expression of IRF7 and provides a positive feedback loop for IFN- $\alpha$ production via IFNAR [34-36]. CpG-B is superior in terms of B cell stimulation, whereas $\mathrm{CpG}-\mathrm{C}$ combines the $\mathrm{B}$ cell-activating properties of $\mathrm{CpG}-\mathrm{B}$ and the IFN- $\alpha$-inducing properties of CpG-A [36, 37].

Here, we investigated the possible roles of pDCs in IgAN by studying its abundance, secretion of IFN- $\alpha$, and the capacity of stimulating $\mathrm{B}$ cell activation and differentiation. We found that $\mathrm{pDCs}$ and plasma cells were significantly more abundant in PBMCs of IgAN patients than in those of healthy controls; meanwhile, plasma IFN- $\alpha$ levels were about 16-fold higher in IgAN patients than in healthy controls. When activated upon pDC-preferred TLR9 ligand
CpG2216 (type CpG-A) ex vivo, PBMCs from IgAN patients secreted more IFN- $\alpha$ than those from control groups, along with augmented plasma cell differentiation. Consistently, IFN- $\alpha$ can stimulate the differentiation of plasma cells, but not the proliferation of B cells in vitro. Furthermore, we found that IFN- $\alpha$ promoted the production of chemokines MCP-1 and IP-10 from human mesangial cells, which resulted in increased transendothelial migration of human $\mathrm{CD}^{+}$and $\mathrm{CD} 14^{+}$cells. This study reveals new pathological roles of $\mathrm{pDC}$ and IFN- $\alpha$ in IgAN, indicating new therapeutic targets for this complex disease.

\section{Material and Methods}

2.1. Study Groups. Biopsy proven, primary IgAN patients were enrolled in The First Affiliated Hospital of Sun Yat-sen University for this study. Healthy donors and patients with lupus nephritis were enrolled as control groups. All recruited donors were of Chinese Han population. All healthy participants are negative for hematuria and proteinuria, with normal renal and liver function, without a past history of kidney diseases. There were no symptoms of infection observed among all participants 4 days before and 3 days after the blood sample collection. None of the patients were treated with steroids and/or immunosuppressive drugs within one year. Patients diagnosed with end-stage renal disease were excluded in this study. All participants were in conformity with written informed consent. This study obtained approval from the ethics review committee of The First Affiliated Hospital of Sun Yat-sen University, Guangzhou, China. This study was conducted in accordance with the guidelines proposed in the Declaration of Helsinki. All adults gave their written informed consent.

The renal histopathology of IgAN patients was classified according to the Oxford classifications [38]. Renal histopathology from all patients was scored by 2 renal pathologists blinded to the clinical data for the 4 pathological variables: the mesangial hypercellularity $(\mathrm{M} 0 \leq 0.5$ or $\mathrm{M} 1 \geq 0.5)$, the segmental glomerulosclerosis ( $\mathrm{S} 0$ absent or $\mathrm{S} 1$ present), the endocapillary hypercellularity (E0 absent or E1 present), and the tubular atrophy/interstitial fibrosis (T0 $\leq 25 \%$; 1 26-50\%; T2 > 50\%) $[39,40]$.

2.2. Reagents. A reverse transcription kit (TAKARA, DRR037A) and real-time master kit (DRR014A) were purchased from Takara Bio Inc. (Otsu, Japan); Trizol reagent (15596018) and DNaseI (AM2235) were from Thermo Fisher Scientific Inc. (Waltham, MA, USA). Antibodies against CD markers (CD3, CD4, CD14, CD19, CD16, CD56, CD20, CD123, HLA-DR, CD11c, and CD38) were purchased from the eBioscience company (San Diego, CA, USA). An IFN- $\alpha$ ELISA kit (3425-1H-6) was provided by the Mabtech company (Cincinnati, Ohio, USA), and recombinant human IFN- $\alpha$ and TNF- $\alpha$ were purchased from PeproTech Inc. (Westlake Village, CA, USA). CpG2216 oligonucleotides were synthesized by Thermo Fisher Scientific Inc. (Waltham, MA, USA). Ig subset antibodies for IgA1, IgA2, and IgG ELISA were purchased from Abcam Inc. (Cambridge, UK), LifeSpan BioSciences Inc. (Seattle, 
WA, USA), and DAKO Inc. (Santa Clara, CA, USA). AntiIFN- $\alpha$ and anti-TLR9 antibody for immunofluorescence staining were purchased from Thermo Fisher Scientific Inc. (Waltham, MA, USA) and Santa Cruz Biotechnology Inc. (Santa Cruz, CA, USA), respectively.

2.3. Analysis of Plasma Cells and PDCs in PBMCs by Flow Cytometry. PBMCs from venous blood with anticoagulant EDTA-K2 were enriched by Ficoll-paque density centrifugation $(800 \times \mathrm{g}$ for 20 minutes). Cells were then washed for four times with phosphate-buffered saline (PBS) with $2 \mathrm{mM}$ EDTA. For pDC analysis, human PBMCs were stained in a combination of fluorochrome-conjugated antibodies for Lin markers (CD3-FITC, CD14-FITC, CD19-FITC, CD20-FITC, CD16-FITC, and CD56-FITC), CD11c-APC, CD123-PE, and HLA-DR-PE Cy7 at $4^{\circ} \mathrm{C}$ for 30 minutes. After washing with $\mathrm{PBS} / 3 \% \mathrm{FBS} / 2 \mathrm{mM}$ EDTA, the cells were analyzed with flow cytometry using a Moflo instrument (Beckman Coulter, Brea, CA, USA). The population of pDC was characterized as surface labeling of $\operatorname{Lin}^{-} \mathrm{CD} 123^{\text {high }} \mathrm{HLADR}^{+} \mathrm{CD} 11 \mathrm{c}^{-}$. For plasma cell analysis in fresh PBMCs, the cells were collected and stained in a combination of fluorochrome-conjugated antibodies (CD19-PE, CD20-FITC, and CD38-PE Cy7) at $4^{\circ} \mathrm{C}$ for 30 minutes and then analyzed with flow cytometry.

2.4. IFN- $\alpha$ and IgA1 Measurement with Enzyme-Linked Immunosorbent Assay (ELISA). The levels of IFN- $\alpha$ in plasma samples and cell culture supernatant were measured by ELISA kits according to the manufacturer's instructions with a detection range of $2-1000 \mathrm{pg} / \mathrm{ml}$. For Ig measurement, samples or Ig subset standards were added to 96-well microplates coated with capture antibody; subsequently, secondary anti-human Ig antibody was added as detection antibody. The plates were incubated at $37^{\circ} \mathrm{C}$ for $3 \mathrm{~h}$, followed by peroxidase-conjugated streptavidin at $37^{\circ} \mathrm{C}$ for 60 min after washing with PBS. The color was developed with $3,3^{\prime}, 5,5^{\prime}$-tetramethylbenzidine (TMB), and the reaction was stopped by adding $100 \mu \mathrm{l}$ of $2 \mathrm{~N} \mathrm{HCl}$ for $5 \mathrm{~min}$ after adding TMB. Optical densities were measured by a microplate reader (Spectra Max M5, Molecular Devices) at $450 \mathrm{~nm}$ wavelength. Results were analyzed statistically together with clinical parameters and renal histopathology to explore the possible relationship between IFN- $\alpha$ and disease severity.

2.5. Immunofluorescence Staining of Tonsil Samples from IgAN Patients. IgAN patients who suffered from tonsillitis and received tonsillectomy were recruited for this study. $4 \%$ paraffin-embedded sections of tonsil samples $(4 \mu \mathrm{m}$ thickness) were deparaffinized with xylene and rehydrated through a graded ethanol series. Before staining, slides were preincubated $1 \mathrm{~h}$ with $\mathrm{PBS} / 0.3 \%$ Triton X-100/3\% bovine serum albumin. Sections were stained with anti-IFN- $\alpha$ and anti-TLR9 antibody for $4 \mathrm{~h}$. Fluorescence signal was amplified with fluorochrome-conjugated secondary antibody, followed by a subsequent DAPI staining and extensive washing with PBS. Sections were observed with a Zeiss LSM 510 Meta Duo Confocal microscope.

2.6. Ex Vivo Stimulation of PBMCs with CPG2216 Oligonucleotides. PBMCs isolated from IgAN patients and healthy donors were separated with ficoll gradient centrifugation and resuspended in RPMI 1640 complete culture medium as described [41]. Cells were plated in 96-well culture plates at the density of $2.5 \times 10^{5} /$ well and cultured at $37^{\circ} \mathrm{C}$ in a $5 \% \mathrm{CO}_{2}$-humidified incubator. Cells were stimulated with $5 \mu \mathrm{g} / \mathrm{ml} \mathrm{CpG2216} \mathrm{(5'GGgggacgatcgtcgGGG}$ $\mathrm{GG}^{\prime}$, the upper case letters indicating phosphorothioate backbones). The supernatant of cells was harvested $24 \mathrm{~h}$ after CpG2216 stimulation and subjected to ELISA for IFN- $\alpha$ measurement. The supernatant was harvested at day 13 after stimulation for Ig analysis with ELISA. The cells were collected at day 7 after CpG2216 stimulation and stained with fluorochrome-conjugated antibodies (anti-CD19-APC, anti-CD20-APC-Cy7, and anti-CD38-PE Cy7) for plasma cell analysis with flow cytometry.

2.7. The Effect of IFN- $\alpha$ on Plasma Cell Differentiation and IgA1 Synthesis. PBMCs isolated from healthy donors were cultured in RPMI 1640 complete culture medium with or without recombinant IFN- $\alpha$ treatment $(2000 \mathrm{IU} / \mathrm{ml})$. Six days after IFN- $\alpha$ stimulation, cells were collected and analyzed for plasma cell differentiation as described above; meanwhile, culture supernatant was collected for IgA1 measurement.

2.8. The Effects of IFN- $\alpha$ on Gene Expression of Human Mesangial Cells. The immortalized human mesangial cell line (HMC) was kindly provided by F. X. Huang (Sun Yat-Sen University, Guangzhou, China) [42] and grown in RPMI 1640 supplemented with $10 \%(v / v)$ fetal bovine serum at $37^{\circ} \mathrm{C}$ in a $5 \% \mathrm{CO}_{2}$-humidified incubator. Equal numbers of mesangial cells were cultured until $80-90 \%$ confluence and subjected to serum starvation for $4-6 \mathrm{~h}$ before treatment. Recombinant IFN- $\alpha(4000 \mathrm{IU} / \mathrm{ml})$ was added to the cell culture medium and incubated with cells for different time periods. Cells were then collected for RNA extraction and later for gene expression analysis.

Samples of total RNA of cells were extracted using Trizol reagent following the manufacturer's instructions. Samples of cDNA were synthesized from RNA using a reverse transcriptase kit according to the manufacturer's manual. Real-time PCR was performed to measure gene expression levels of TGF- $\beta$, VEGFA, RANTES, ICAM-1, IL-6, IFNAR1, IP-10, iNOS, TNF- $\alpha$, IL-1 $\beta$, PDGF-BB, MCP-1, MCP3, VCAM-1, MIP-1b, and CCL17 in an ABI 7900HT instrument (Applied Biosystems, South San Francisco, CA, USA) for 40 cycles $\left(95^{\circ} \mathrm{C}\right.$ for $30 \mathrm{sec}, 58^{\circ} \mathrm{C}$ for $30 \mathrm{sec}$, and $72^{\circ} \mathrm{C}$ for $30 \mathrm{sec}$ for each cycle). Data were expressed as fold changes using the $\Delta \Delta \mathrm{Ct}$ method [43] with GAPDH as an internal control.

\subsection{Transendothelial Migration (TEM) of $C D 14^{+}$and $C D 4^{+}$ Cells Mediated by Conditioned Medium from HMC Treated with IFN- $\alpha$}

2.9.1. Preparation of $C D 14^{+}$and $C D 4^{+}$Cells. PBMCs obtained from healthy donors were separated with ficoll gradient centrifugation as described above. $\mathrm{CD} 14^{+}$and $\mathrm{CD} 4^{+}$cells were enriched from harvested PBMCs by sorting in Moflo instrument after cells were labeled with fluorochrome- 

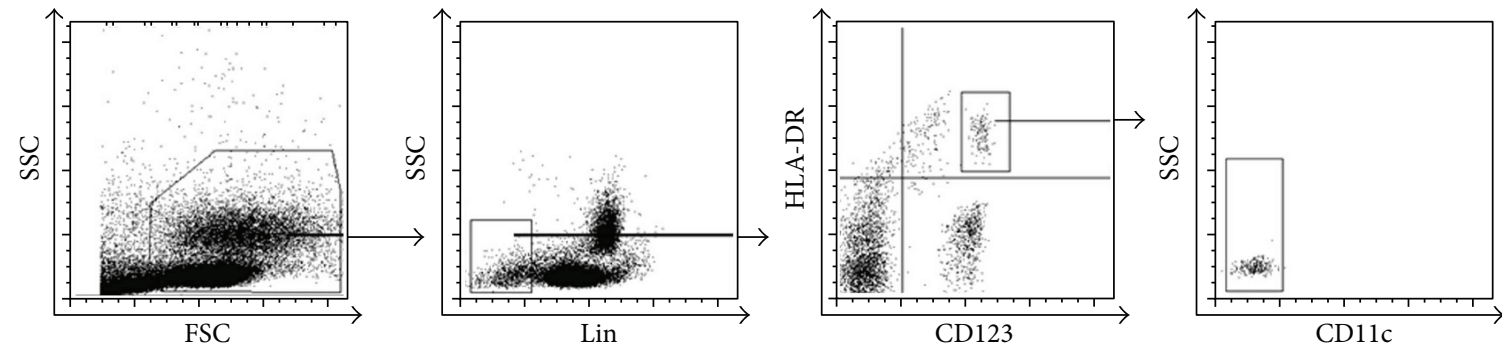

(a)

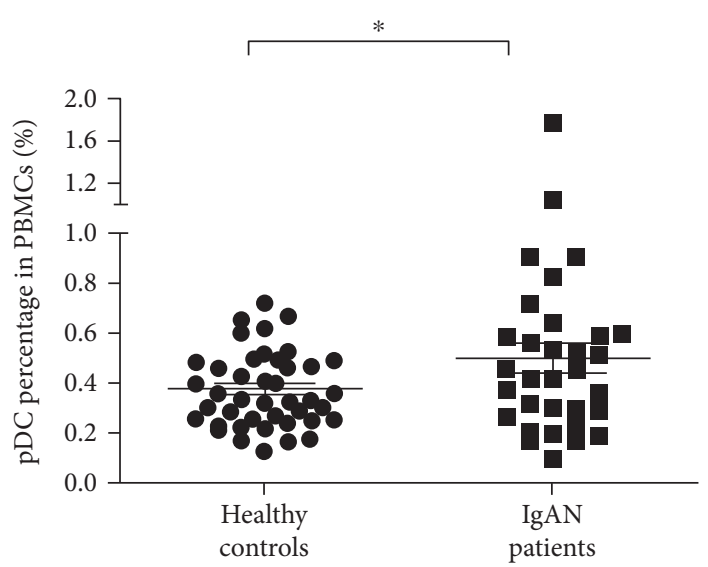

(b)

FIGURE 1: The percentages of pDCs were increased in PBMCs of IgAN patients. Peripheral blood mononuclear cells (PBMCs) of donors were prepared by ficoll-paque density centrifugation and subjected to flow cytometry analysis. (a) The surface phenotype of pDCs was defined as $\mathrm{Lin}^{-} \mathrm{CD} 123^{\text {high }} \mathrm{HLA}-\mathrm{DR}{ }^{+} \mathrm{CD} 11 \mathrm{c}^{-}$. (b) The percentages of pDCs in PBMCs from IgAN patients and healthy donors were analyzed. ${ }^{*} p<0.05$.

conjugated antibodies against a CD14 or CD4 marker. $\mathrm{CD} 14^{+}$monocytes/macrophages were resuspended at a density of $1 \times 10^{6}$ cells $/ \mathrm{ml}$ in RPMI $1640 / 0.5 \%$ FBS medium. $\mathrm{CD}^{+} \mathrm{T}$ cells were stimulated with anti-CD3 antibody $(5 \mu \mathrm{g} / \mathrm{ml})$ overnight and resuspended at $1 \times 10^{7}$ cells $/ \mathrm{ml}$ in RPMI 1640/0.5\%FBS medium.

2.9.2. Preparation of Conditioned Medium from Human Mesangial Cells Treated with IFN- $\alpha$. Human mesangial cells in RPMI $1640 / 10 \%$ FBS were treated with IFN- $\alpha$ at $4000 \mathrm{IU} / \mathrm{ml}$ for $6 \mathrm{~h}$. Cells were washed once with plain culture medium, and culture was resumed in fresh RPMI 1640 with $0.5 \%$ fetal bovine serum for $16-18 \mathrm{~h}$. Conditioned medium was collected by centrifugation at $1600 \mathrm{rpm}$ for $6 \mathrm{~min}$ at $4^{\circ} \mathrm{C}$. Aliquots were stored at $-20^{\circ} \mathrm{C}$ for future use.

Human umbilical vascular endothelial cells (HUVECs) were prepared by collagenase treatment of umbilical cords as previously described [44]. Primary endothelial cells at passage three were plated at a density of $2 \times 10^{4}$ cells/well onto gelatin-coated transwells ( $5 \mu \mathrm{M}$ pore size, cat. 3421 , Corning, New York, USA) and cultured until 100\% confluence in ECM medium with $20 \%$ FBS, followed by an overnight stimulation of $10 \mathrm{ng} / \mathrm{ml}$ TNF- $\alpha$. HUVECs were washed once and then balanced for at least $1 \mathrm{hr}$ with RPMI 1640/0.5\% FBS at $37^{\circ} \mathrm{C}$. Conditioned medium harvested from HMC was added to the bottom chambers of a transwell $(0.6 \mathrm{ml} /$ well $)$. CD $14^{+}$ and $\mathrm{CD} 4^{+}$cells were, respectively, added to the top wells at the density of $1 \times 10^{5}$ cells $/ 100 \mu \mathrm{l}$ and $1 \times 10^{6}$ cells $/ 100 \mu \mathrm{l}$. A transwell plate was incubated in a $\mathrm{CO}_{2}$ incubator at $37^{\circ} \mathrm{C}$, allowing cell migration for $6-12 \mathrm{~h}$. Cells which migrated into the bottom wells were harvested with trypsin and centrifugation, followed by Hoechst staining. Migrated CD $14^{+}$or $\mathrm{CD} 4^{+}$ cells were examined with a fluorescence microscopy (Leica).

2.10. Statistical Analysis. Data was expressed as mean \pm standard error value and treated with Student's $t$-test. For data of three and more groups were involved, we carried out one-way ANOVA and further post hoc test when $p<0.05$. The correlation was tested with Pearson's correlation coefficients and presented with a scatter plot. Statistical analysis was performed with the SPSS 18.0 software. All statistical assessments were two-sided using a significance value of less than 0.05 .

\section{Results}

3.1. Plasmacytoid Dendritic Cells and Its Signature Cytokine IFN- $\alpha$ Were More Abundant in Peripheral Blood of IgAN Patients. As we investigated the abundance of pDCs in PBMCs of IgAN patients and healthy controls, multiple CD markers labeling (Lin(CD3/14/19/20/16/56) $)^{-}$CD $123^{\text {high }}$ HLA-DR ${ }^{+} \mathrm{CD} 11 \mathrm{c}^{-}$) were used to characterize this cell population (Figure 1(a)). The percentage of pDCs in PBMCs was found significantly higher in IgAN patients than in healthy controls $(0.51 \%$ versus $0.37 \%, p=0.029)$ (Figure $1(\mathrm{~b})$ ). IFN- $\alpha$ is the most remarkable cytokine for $\mathrm{pDC}$, and we found that 


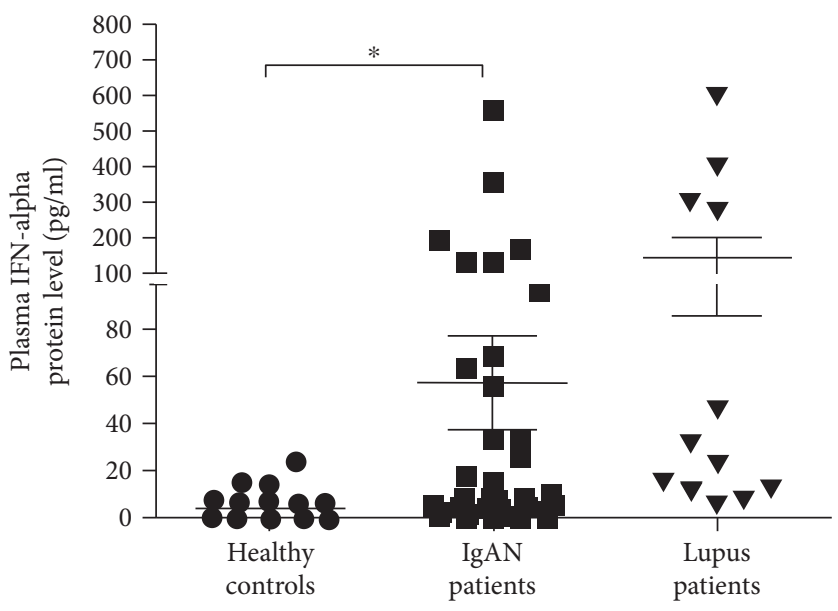

(a)

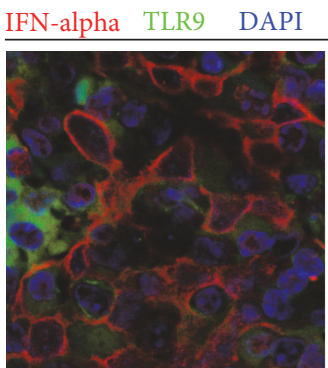

IgAN patient 1

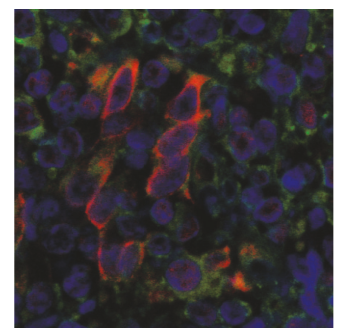

IgAN patient 2

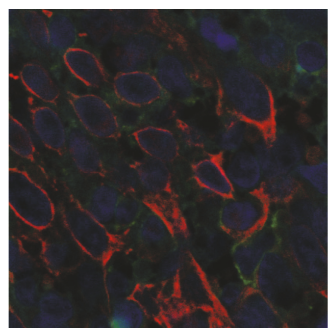

IgAN patient 3

(b)

FIGURE 2: (a) Concentrations of IFN- $\alpha$ proteins in plasma were measured in different groups. PBMCs of different donors were prepared by ficoll-paque density centrifugation, and plasma in upper layer was harvested for ELISA analysis. ${ }^{*} p<0.05$. (b) Paraffin-embedded sections of tonsil from IgAN patients with tonsillitis were stained for IFN- $\alpha$ and TLR9 expression.

TABLE 1: Clinical and demographic features of IgAN patients and healthy controls.

\begin{tabular}{|c|c|c|c|c|}
\hline \multirow{2}{*}{ Feature } & \multicolumn{2}{|c|}{$\mathrm{pDC}$} & \multicolumn{2}{|c|}{ IFN-alpha } \\
\hline & Healthy controls & IgAN patients & Healthy controls & IgAN patients \\
\hline Gender (male/female) & $12 / 21$ & $11 / 21$ & $10 / 22$ & $9 / 25$ \\
\hline Age $(y r)$ & $33.6 \pm 9.3$ & $32.5 \pm 9.7$ & $35.8 \pm 9.6$ & $31.7 \pm 9.3$ \\
\hline Serum creatinine $(\mu \mathrm{M})$ & & $81.3 \pm 32.8$ & & $69 \pm 24$ \\
\hline 24-hour proteinuria (g/24 h) & & $1.00 \pm 0.78$ & & $0.74 \pm 0.48$ \\
\hline eGFR & & $98.5 \pm 29.1$ & & $108.4 \pm 23.9$ \\
\hline
\end{tabular}

plasma IFN- $\alpha$ levels were significantly upregulated in IgAN patients $(56.9 \pm 20.2 \mathrm{pg} / \mathrm{ml})$ than in healthy donors $(3.4 \pm 1.0 \mathrm{pg} / \mathrm{ml})$. Plasma levels of IFN $-\alpha$ in IgAN patients were lower than those in patients of lupus nephritis $(143.7 \pm$ $57.8 \mathrm{pg} / \mathrm{ml}$ ) (Figure 2(a)). Furthermore, we examined the expression of IFN- $\alpha$ and TLR9 in tonsil samples of IgAN patients who suffered from tonsillitis. We found that IFN- $\alpha$ was evidently expressed in tonsillar cells of IgAN patients; meanwhile, TLR9 was richly expressed in IFN- $\alpha$-positive cells (Figure 2(b)).

Demographic and clinical profile of IgAN patients and controls is listed in Table 1 . When investigating the correlation among plasma IFN- $\alpha$ concentrations and clinical features, plasma IFN- $\alpha$ levels exhibited significant and positive association with 24-hour proteinuria $(r=0.34, p=0.04)$ and anti-Dnase B titer $(r=0.48, p=0.005)$ in patients with IgAN (Table 2). Regarding renal histopathology, we found that $\mathrm{pDC}$ percentages were positively associated with renal IgM deposition in IgAN patients $(r=0.45, p=0.009)$. Also, plasma IFN- $\alpha$ concentrations were significantly associated with tubular atrophy/interstitial fibrosis grade $(r=0.37$, $p=0.03)$, as well as renal $\operatorname{IgM}$ deposition $(r=0.34, p=0.04)$ in IgAN patients (Table 2).

3.2. pDC-Preferred CpG Stimulation Induced IFN- $\alpha$ Secretion and Plasma Cell Differentiation in PBMCs of IgAN Patients. CpG2216 was a potent activator for TLR9 expressed on pDCs, and we employed it to study the response of 
TABLE 2: Association of pDC and IFN-alpha with clinical parameters and renal histopathology in IgAN patients.

\begin{tabular}{|c|c|c|c|c|}
\hline \multirow[t]{2}{*}{ Feature } & \multicolumn{2}{|c|}{ pDC percentage in PBMCs } & \multicolumn{2}{|c|}{$\begin{array}{l}\text { IFN-alpha protein levels } \\
\text { in plasma }\end{array}$} \\
\hline & Pearson's $r$ & $p$ value & Pearson's $r$ & $p$ value \\
\hline Age (yr) & 0.05 & 0.76 & 0.15 & 0.39 \\
\hline Serum creatinine $(\mu \mathrm{M})$ & 0.027 & 0.88 & -0.09 & 0.58 \\
\hline eGFR $\left(\mathrm{ml} / \mathrm{min}\right.$ per $\left.1.73 \mathrm{~m}^{2}\right)$ & 0.005 & 0.99 & -0.02 & 0.91 \\
\hline 24-hour proteinuria $(\mathrm{g} / 24 \mathrm{~h})$ & 0.11 & 0.53 & 0.34 & $0.04^{*}$ \\
\hline Serum IgA $(g / l)$ & -0.29 & 0.09 & 0.07 & 0.69 \\
\hline Serum IgG (g/l) & 0.03 & 0.85 & 0.05 & 0.78 \\
\hline Serum IgM $(g / l)$ & 0.22 & 0.29 & 0.08 & 0.67 \\
\hline Serum C3 (g/l) & 0.14 & 0.48 & -0.16 & 0.36 \\
\hline CRP (mg/l) & 0.33 & 0.09 & -0.12 & 0.49 \\
\hline $\mathrm{SAA}(\mathrm{mg} / \mathrm{l})$ & 0.27 & 0.16 & -0.11 & 0.51 \\
\hline $\operatorname{ASO}(\mathrm{Ku} / \mathrm{l})$ & 0.31 & 0.11 & 0.22 & 0.20 \\
\hline Anti-Dnase B (U/ml) & -0.21 & 0.28 & 0.48 & $0.005^{*}$ \\
\hline Mesangail hypercellularity (M0/M1) & 0.09 & 0.62 & -0.07 & 0.69 \\
\hline Endocapillary hypercellularity (E0/E1) & 0.04 & 0.84 & -0.06 & 0.63 \\
\hline Tubular atrophy/ interstitial fibrosis (T0/T1/T2) & 0.03 & 0.89 & 0.37 & $0.03^{*}$ \\
\hline Segmental sclerosis (S0/S1) & 0.17 & 0.33 & 0.11 & 0.52 \\
\hline Kidney IgA intensity & -0.23 & 0.20 & 0.03 & 0.85 \\
\hline Kidney IgG intensity & 0.11 & 0.55 & -0.04 & 0.81 \\
\hline Kidney IgM intensity & 0.45 & $0.009^{* *}$ & 0.34 & $0.04^{*}$ \\
\hline Kidney C3 intensity & -0.30 & 0.09 & 0.15 & 0.40 \\
\hline
\end{tabular}

C3: complement 3; CRP: C-reactive protein; SAA: serum amyloid A protein; ASO: antistreptolysin O. ${ }^{*} p<0.05 ;{ }^{* *} p<0.001$.

PBMCs culture from IgAN patients. First, we confirm that IFN- $\alpha$ was mostly secreted by pDCs but not by other cells from PBMCs after CpG2216 stimulation (Supplemental Figure 1). Also, as shown in Supplemental Figure 2, CpG ODN 2216, but not control ODN, was able to provoke the synthesis of IFN- $\alpha$; meanwhile, two reported inhibitory ODNs [45-47] of TLR9 suppressed CpG2216-mediated IFN- $\alpha$ secretion to less than 50\% (Supplemental Figure 2).

When subjected to CpG2216 stimulation, PBMCs from IgAN patients secreted more IFN- $\alpha$ proteins (4338 \pm $1374 \mathrm{pg} / \mathrm{ml}$ ) into supernatant than those from healthy controls $(1600 \pm 508 \mathrm{pg} / \mathrm{ml}$ ) (Figure 3(a)). Moreover, the secretion of IgG antibodies from PBMCs of IgAN patients was significantly stronger than that from healthy controls $(3425 \pm 525$ versus $1788 \pm 251 \mathrm{ng} / \mathrm{ml}$ ) (Figure 3(c)). A similar result was found for IgA2 antibody secretion $(593 \pm 133$ versus $155 \pm 36 \mathrm{ng} / \mathrm{ml}$ ) (Figure $3(\mathrm{~d})$ ), but not for $\operatorname{IgA} 1$ antibodies (Figure 3(b)).

We further investigated the regulation of plasma cell differentiation by TLR9 activation in PBMCs culture of IgAN patients. After CpG2216 stimulation for 6 days, CD $19^{+} \mathrm{B}$ cells became activated in PBMCs and differentiated into plasma cells by labeling as $\mathrm{CD} 19^{+} \mathrm{CD} 20{ }^{\text {low }} \mathrm{CD} 38^{\text {high }}$ (Figure 4(a)). In contrast to the CpG2216-treated group, the vehicle-treated group showed very low level of plasma cell differentiation (Supplemental Figure 3). Furthermore, CpG2216 did not significantly enhance CD19 ${ }^{+}$cell proliferation in PBMCs culture from IgAN patients compared with healthy controls $(12.37 \pm 1.1 \%$ versus $10.44 \pm 0.74 \%, p=$ 0.49). However, we found that CpG2216 stimulation demonstrated superior capability in directing $\mathrm{CD} 19^{+} \mathrm{B}$ cells differentiating into plasma cells in PBMCs culture of IgAN patients, resulting in $50 \%$ increase of plasma cell generation than healthy controls $(4.56 \pm 0.6 \%$ versus $3.06 \pm 0.37 \%$, $p=0.04$ ) (Figure 4(b)). These data suggested that the activation of TLR9 of pDCs from IgAN patients was more potent in promoting the differentiation of plasma cells, as compared with healthy controls.

We also investigated in vivo abundance of $\mathrm{CD}_{1} 9^{+}$cells and plasma cells in IgAN patients. Consistent with ex vivo results, the percentage of $\mathrm{CD}^{+}{ }^{+}$cells was not significantly higher in freshly isolated PBMCs of IgAN patients than in healthy controls $(8.16 \pm 0.79 \%$ versus $10.10 \pm 0.99 \%$, $p=0.23$ ), but the percentage of plasma cells in freshly isolated PBMCs was about 56\% higher in IgAN patients than in healthy controls $(0.39 \pm 0.04 \%$ versus $0.25 \pm 0.05 \%$, $p=0.04$ ) (Figure 4(c)).

\subsection{IFN- $\alpha$ Treatment Led to More Plasma Cell Differentiation} and IgA1 Production from B Cells of Healthy Donors. To test whether IFN- $\alpha$ was important for plasma cell differentiation, PBMCs of healthy donors were treated with or without IFN- $\alpha(2000 \mathrm{IU} / \mathrm{ml})$ for 6 days. As shown in Figure 5, the proliferative effects of IFN- $\alpha$ on $\mathrm{CD}_{1}{ }^{+}$cell proliferation were only observed in 3 out of 7 donors (Figure 5(a)), whereas the proliferative effects of IFN- $\alpha$ on plasma cell generation were 


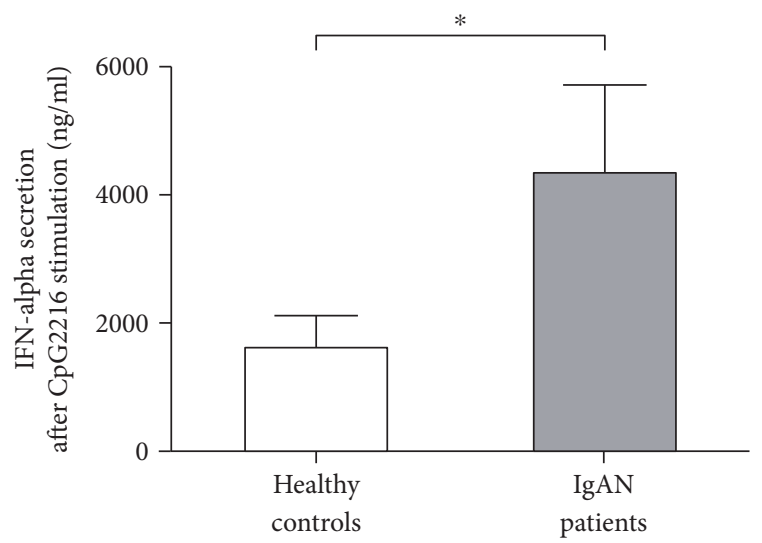

(a)

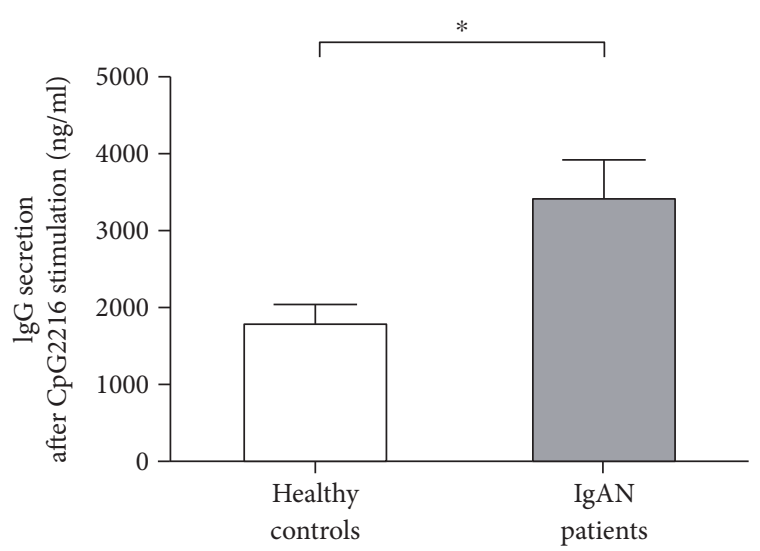

(c)

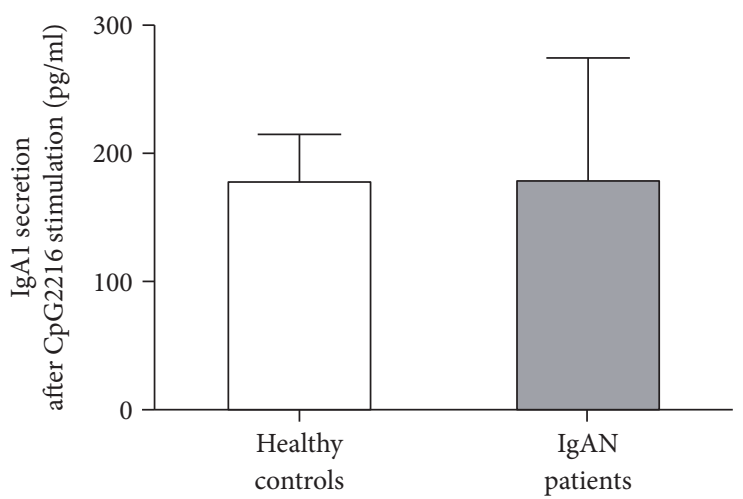

(b)

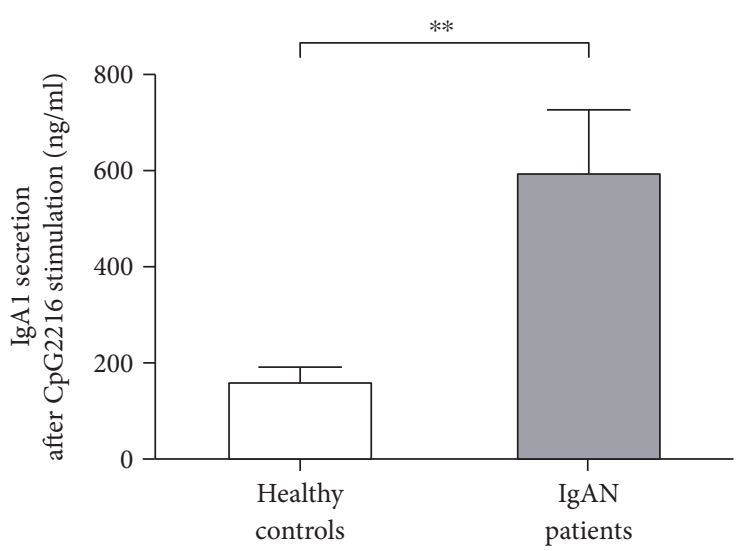

(d)

FIGURE 3: Secretion of IFN- $\alpha$ was increased in PBMCs of patients of IgAN after CpG2216 stimulation. PBMCs of different donors (healthy donors, $n=23$; IgAN patients, $n=14$ ) were prepared by ficoll-paque density centrifugation and cultured with pDC-preferred CpG2216 for different days, and the supernatant samples were collected for measuring IFN- $\alpha$, IgA1, IgA2, and IgG levels. ${ }^{*} p<0.05 ;{ }^{* *} p<0.01$.

all observed in 7 out of 7 donors (Figure 5(b)). We also found that IgA1 synthesis was increased in all 7 donors (Figure 5(c)). This result indicated that IFN- $\alpha$ exerted a positive impact on plasma cell differentiation and IgA1 production, but not on $\mathrm{CD} 9^{+}$cell proliferation.

\subsection{IFN- $\alpha$ Promoted Inflammatory Gene Expression in} Human Mesangial Cells and Enhanced Transendothelial Migration of Human $\mathrm{CD} 4^{+}$Cells and $\mathrm{CD} 14^{+}$Cells. To test whether IFN- $\alpha$ imposes provocative influence on the expression of growth factors, proinflammatory factors, chemokines, and bioactive molecules in human mesangial cells, we analyzed the expression of IFNAR1, TGF- $\beta 1$, VEGFA, PDGFBB, RANTES, ICAM, IP-10, MCP-1, iNOS, IL-6, IL- $1 \beta$, and TNF- $\alpha$ after IFN- $\alpha$ treatment. As shown in Figure 6, IFN- $\alpha$ receptor was richly expressed in human mesangial cells and significantly upregulated after IFN- $\alpha$ treatment. IFN- $\alpha$ also enhanced the expression of IL-6, IP-10, and MCP-1 in human mesangial cells after $2 \mathrm{~h}$ and $6 \mathrm{~h}$ of treatment. IFN- $\alpha$ imposed a certain effect on the expression of VEGFA and iNOS whereas less effect on the expression of TGF- $\beta 1$, RANTES, ICAM, TNF- $\alpha$, IL- $1 \beta$, and PDGF-BB. Baselines of mRNA levels of chemokines MCP3, VCAM-1,
MIP-1 $\beta$, and CCL17 were very low in HMCs as detected by real-time RT-PCR, no matter with or without IFN- $\alpha$ treatment (data not shown).

The expression levels of chemokines MCP-1 and IP-10 were increased in human mesangial cells after IFN- $\alpha$ treatment; therefore, we investigated their ability for attracting leukocytes migrating though endothelial cells. As demonstrated in Figure 7, human $\mathrm{CD} 14^{+}$cells and $\mathrm{CD} 4^{+}$cells from 4 human donors migrated with higher efficiency in response to conditioned medium of human mesangial cell pretreated with IFN- $\alpha$. For $\mathrm{CD}^{+} \mathrm{T}$ cell migration, the numbers of migrated cells of 4 donors attracted by IFN- $\alpha$ pretreated supernatant were, respectively, 1.77-, 2.52-, 2.63-, and 1.62fold of those migrating towards unconditioned supernatant. In the case of $\mathrm{CD} 14^{+}$monocytes/macrophages, the numbers of migrated cells attracted by IFN- $\alpha$ pretreated supernatant were 1.40-, 1.75-, 1.65-, and 1.87-fold of those migrating towards unconditioned supernatant.

\section{Discussion}

pDC and its secreted cytokine IFN- $\alpha$ in autoimmune diseases such as systemic lupus erythematosus and psoriasis have 


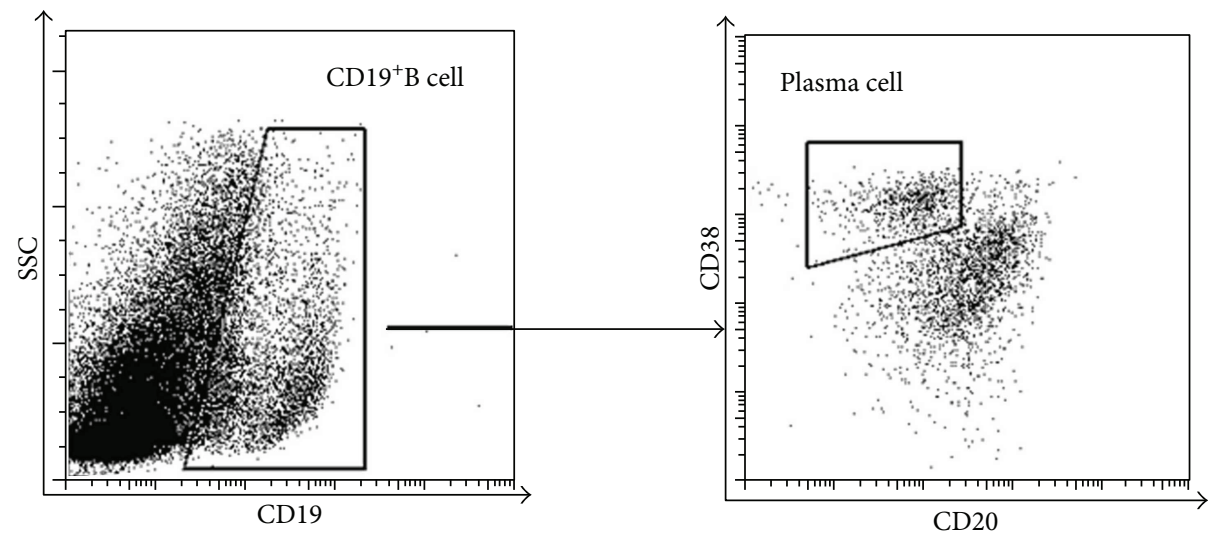

(a)
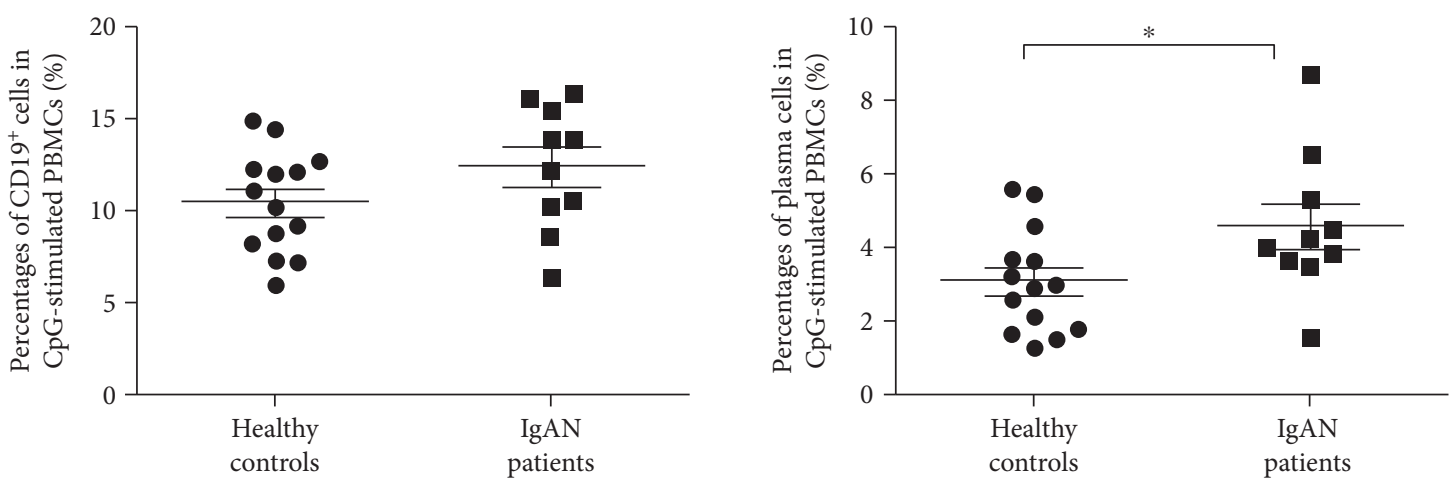

(b)
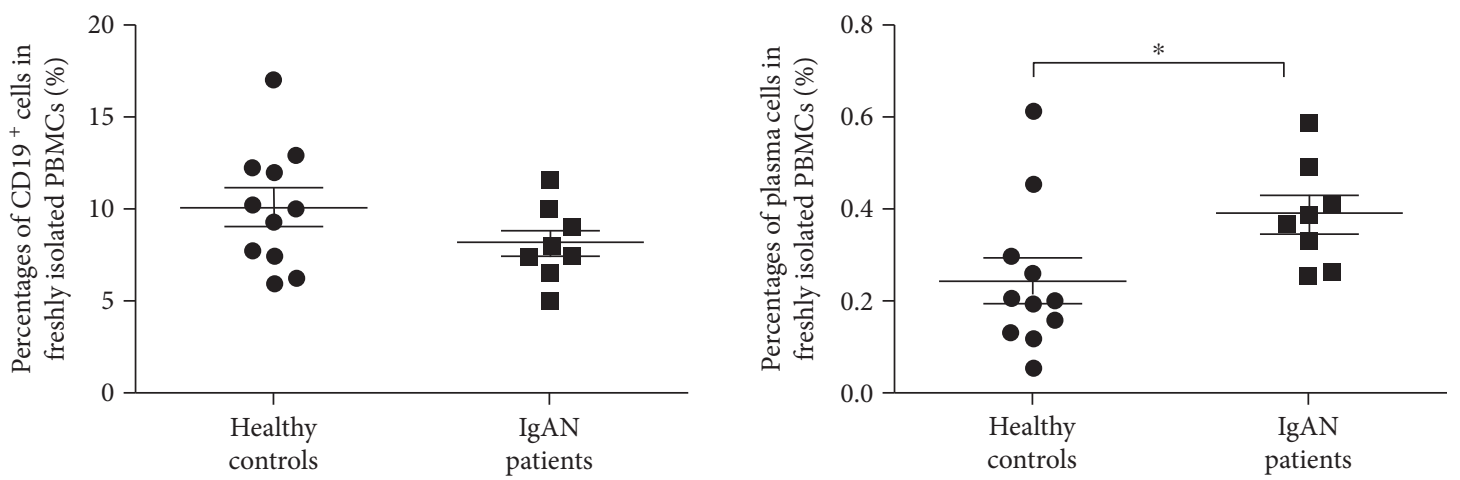

(c)

FIGURE 4: Plasma cell differentiation was augmented in CpG2216-activated PBMCs ex vivo. PBMCs of different donors were prepared by ficoll-paque density centrifugation and cultured with pDCs-preferred CpG2216 for 6 days, followed by surface marker labeling and analysis in flow cytometry. (a) $\mathrm{CD} 19^{+}$cells differentiated into plasma cells $\left(\mathrm{CD} 19^{+} \mathrm{CD} 38^{\text {high }} \mathrm{CD} 20^{\text {low }}\right.$ ) after $\mathrm{CpG} 2216$ stimulation for 6 days. (b) The percentage of $\mathrm{CD} 19^{+}$cells and plasma cells in ex vivo PBMCs culture after 6 days (healthy donors, $n=14$; IgAN patients, $n=10)$. (c) The percentage of $\mathrm{CD}_{1} 9^{+}$cells and plasma cells in fresh PBMCs from IgAN patients and healthy controls (healthy donors, $n=11$; IgAN patients, $n=8) .{ }^{*} p<0.05$.

been addressed for their roles in eliciting inflammatory response and tissue damage [48-50]. High levels of IFN- $\alpha$ were found in sera of lupus patients, and large numbers of pDCs were found in skins of lupus patients [51-53]. In addition, a global gene expression profiling of PBMCs from lupus patients showed a high number of IFN- $\alpha$ responsive genes was abnormally expressed [54]. In the downstream, IFN- $\alpha$ leads to the enhanced maturation of dendritic cells, inflamed autoreactive $\mathrm{T}$ cell, diminished regulatory $\mathrm{T}$ cell activity, and augmented response of $B$ cells $[55,56]$. However, the status of $\mathrm{pDC}$ and IFN- $\alpha$ in the pathogenesis of IgAN has not been well studied. To our knowledge, this is the first study reporting that $\mathrm{pDC}$ and its secreted IFN- $\alpha$ induced by TLR9 activation enhance plasma cell differentiation and further facilitate monocytes/macrophages and $\mathrm{T}$ lymphocyte infiltration across endothelial cell monolayer in IgAN. TLR9 was richly expressed on pDCs, and its activation via CpG-A mainly boosts the synthesis of type I interferon and promotes 


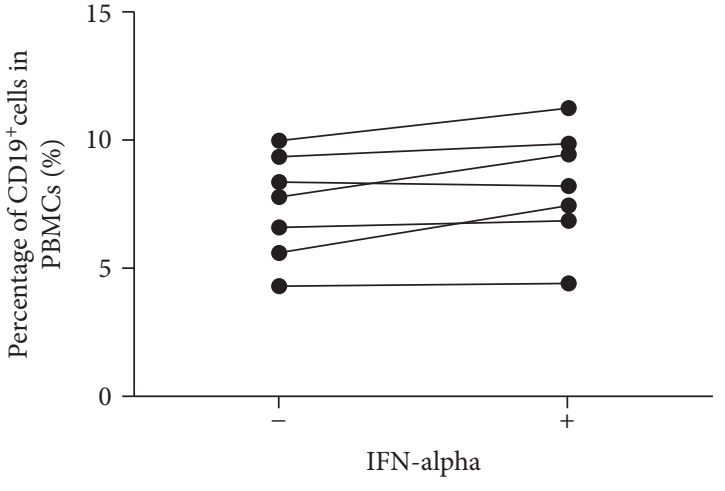

(a)

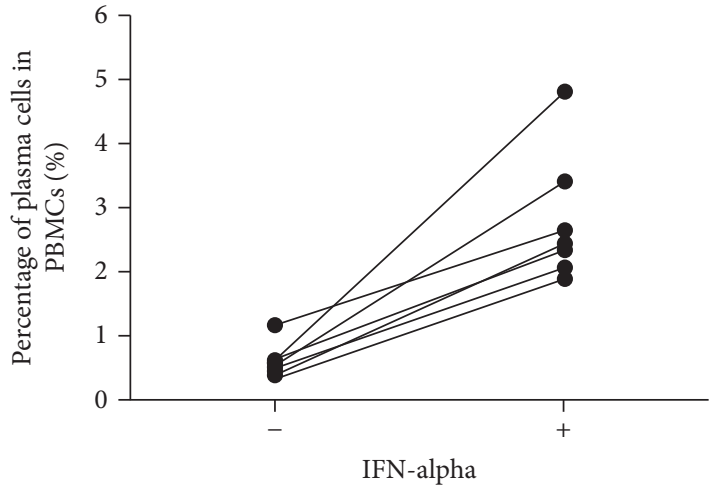

(b)

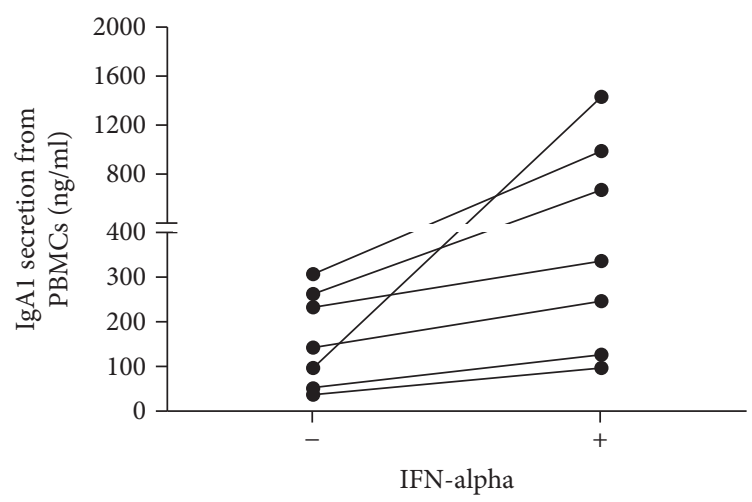

(c)

FIGURE 5: IFN- $\alpha$ promote the differentiation of plasma cells from PBMCs ex vivo. PBMCs of different healthy donors $(n=7)$ were prepared by ficoll-paque density centrifugation and cultured with or without IFN- $\alpha(2000 \mathrm{IU} / \mathrm{ml})$ plus anti-IgM antibody for 6 days, followed by surface markers labeling and analysis in flow cytometry. (a) The percentage of CD19 ${ }^{+}$cells in PBMCs after IFN- $\alpha$ treatment for 6 days. (b) The percentage of plasma cells in PBMCs after IFN- $\alpha$ treatment for 6 days. (c) IgA1 secretion from PBMCs after IFN- $\alpha$ treatment for 6 days.

pDC maturation, while TLR9 activation on B cells via CpG-B induces B cell maturation and Ig synthesis $[57,58]$. In a ddY mouse model of IgA nephropathy, treatment with CpG-A but not with CpG-B resulted in increased serum level of IgA-IgG2a immune complex and its glomerular depositions, along with extension of mesangial proliferative lesion [19]. Activation of TLR9 in germinal center B cells induced APRIL synthesis, which induces IgA secretion in IgAN [59]. We found that $\mathrm{pDCs}$ were more abundant in IgAN patients and TLR9 activation via CpG-A led to more IFN- $\alpha$ production ex vivo, which promote plasma cell differentiation. This result is further supported by the evidence that plasma cells were more abundant in freshly collected peripheral blood cells of IgAN patients. Previous evidence from isolated tonsillar cells showed that TLR9 was expressed in $\mathrm{CD} 19^{+} \mathrm{B}$ cells and $\mathrm{BDCA}^{+}$pDCs in the tonsils of IgAN patients [20]. Though BDCA2 is a specific marker for pDC in immunostaining, it was reported that BDCA2 was an inhibiting signal for TLR9-mediated IFN- $\alpha$ synthesis in pDCs [60] and $\mathrm{BDCA}^{+}$pDC produced a very low amount of IFN- $\alpha$ in lymph node [61]. From our result, it was found that in the tonsil sample of IgAN patients, TLR9 was richly stained in IFN- $\alpha$ positive cells, indicating that TLR9 was closely related with IFN- $\alpha$ production in IgAN. Combining all these data, it indicates that TLR9 was a critical factor in mediating the aberrant IFN- $\alpha$ secretion, B cell differentiation, and Ig synthesis in IgAN. One point worthy to be mentioned is that IFN- $\alpha$ was also observed in some tonsillar cells which were negative for TLR9 expression in our study. It is known that TLR7 expressed in pDCs or TLR3 expressed in mDCs or other resident cells were potent mediators for IFN- $\alpha$ production $[28,58,62]$. Whether these TLR molecules contributed to augmented IFN- $\alpha$ production in IgAN needs further exploration.

As a virus-defending cytokine, IFN- $\alpha$ exerts astonishing influences in autoimmune disease systemic lupus erythematosus by activating dendritic cell maturation, antibodies production, immunoglobulin class switching, and $\mathrm{T}$ cell subset differentiation [62]. We found that average plasma concentration of IFN- $\alpha$ in IgAN patients is about 16 times of that in healthy donors. Besides, ex vivo activation of PBMCs of IgAN patients results in more IFN- $\alpha$ synthesis, which directly promotes the differentiation of plasma cells in vitro. Supportively, Giordani et al. found that IFN- $\alpha$ promoted the plasma cell differentiation from both naive $B$ cells and memory B cells upon TLR9 stimulation [63]. For the underlying mechanism, they found that increased IL-6 expression after IFN- $\alpha$ treatment is very important for B cell differentiation [63-65]. Furthermore, IFN- $\alpha$ was capable of promoting the expression of CD69, CD86, and CD25 

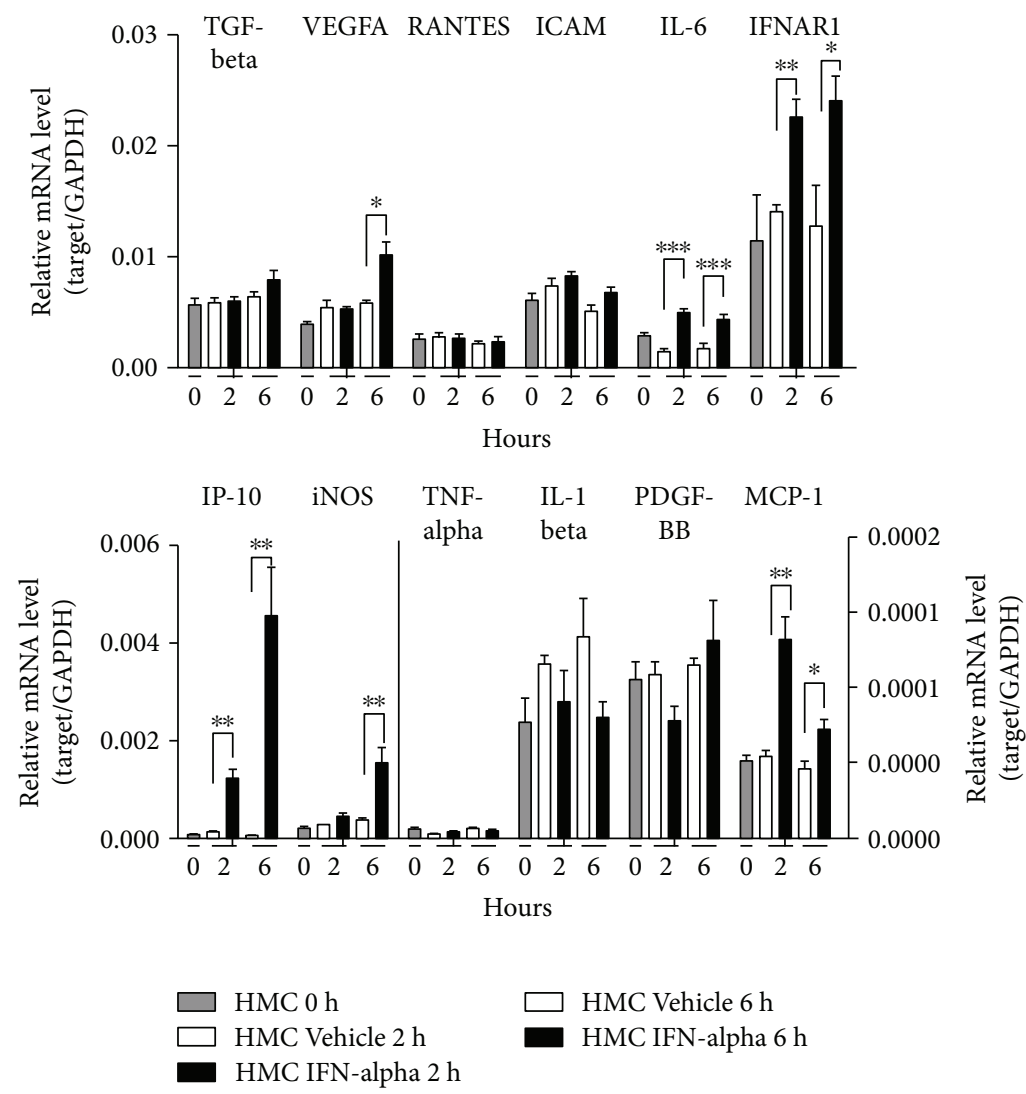

FIGURE 6: Regulation of gene expression by IFN- $\alpha$ in human mesangial cells. Human mesangial cells were subjected to serum starvation for $6 \mathrm{~h}$, followed by IFN- $\alpha$ treatment $(4000 \mathrm{IU} / \mathrm{ml})$ for varied time points $(0 \mathrm{~min}, 2 \mathrm{~h}$, and $6 \mathrm{~h})$. The mRNA levels of TGF-beta, VEGFA, RANTES, ICAM, IL-6, IFNAR1, IP-10, iNOS, TNF- $\alpha$, IL-1 $\beta$, PDGF-BB, and MCP-1 were measured by real-time PCR. This experiment was repeated independently at least three times, and representative data are shown. ${ }^{*} p<0.05,{ }^{* *} p<0.01$, and ${ }^{* * *} p<0.001$.

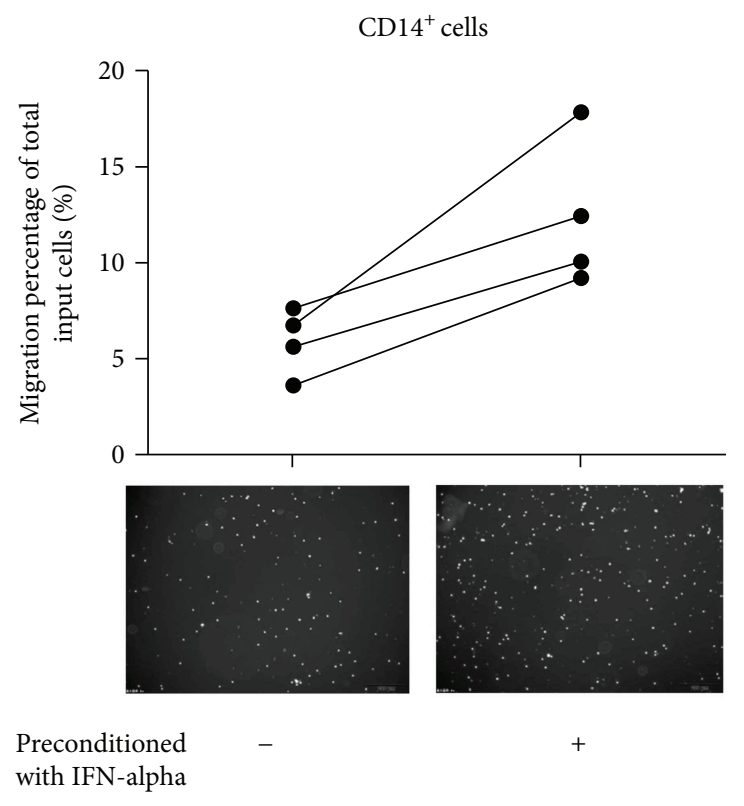

(a)

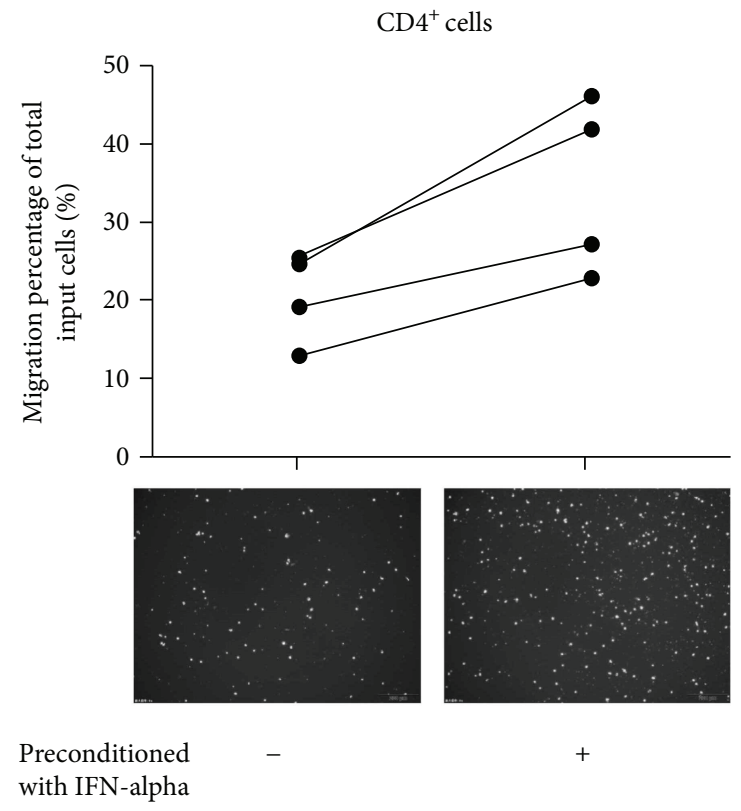

(b)

FIGURE 7: Transendothelial migration of $\mathrm{CD} 4^{+}$cells and $\mathrm{CD} 4^{+}$cells was promoted by IFN- $\alpha$-conditioned HMC supernatant. HUVEC cells were cultured onto inserts of transwells, and the bottom champers were filled with culture supernatant of HMC preconditioned with recombinant IFN- $\alpha$ or vehicles. CD $14^{+}$cells and $\mathrm{CD}^{+}$cells were sorted from fresh PBMCs of donors $(n=4)$ by flow cytometry and loaded on the upper wells. After migrating for 6-12 h, migrated cells in the bottom champers were collected and counted in high power field. 
molecules on B cells, as well as inhibiting Fas-mediated apoptosis of B cell, thus leading to low threshold for B cell induction and fast antibody responses [66, 67]. All these data support the notion that IFN- $\alpha$ is helpful for expanding $B$ cell survival and plasma cell differentiation in IgAN patients. Our result is beneficial for explaining that bone marrow-resident IgA-producing B cells were upregulated in IgAN patients [68], since these augmented plasma cells may migrate back to bone marrow or inflamed tissue and became long-lived plasma cells which contribute to the autoantibody production in autoimmunity diseases with renal manifestation [69-71]. We also found that IFN- $\alpha$ was positively correlated with 24-hour proteinuria in IgAN patients. In murine lupus model, in vivo sustained expression of IFN- $\alpha$ induced severe proteinuria, immune complex deposition, autoantibody production, and lethal glomerulonephritis [72-74]. Very low dose delivery of exogenous IFN- $\alpha(<12.5 \mathrm{pg} / \mathrm{ml}$ in circulation $)$ could elicit proteinuria in lupus-prone mice [73], which strongly indicated IFN- $\alpha$ was very potent in inducing proteinuria. Given all these facts, it is tempting to speculate that higher IFN- $\alpha$ level was involved in proteinuria and glomerulonephritis development in IgA nephropathy as it does in lupus.

It is intriguing that $\operatorname{IgA} 1$ synthesis in CpG-stimulated PBMCs from IgAN patients was not increased whereas IFN- $\alpha$ can promote IgA1 synthesis in vitro. An explanation is that besides IFN- $\alpha$, there are other cytokines such as IL-6, IL-12, APRIL, and BAFF elicited by $\mathrm{pDC}$ that can influence the synthesis of antibody subsets and plasma cell differentiation [75-79]. However, how these cytokines are influenced by pDC in IgAN patients was unclear and needs further investigation. On the other side, the production of IgG and IgA2 antibodies was enhanced in PBMCs of IgAN patients after CpG2216 stimulation ex vivo. It was reported that pDC combined with $\mathrm{CpG}$ induced IgM and IgG synthesis in B cells, and IFN- $\alpha$ can further amplify the strength of CpG $[63,80]$. Another interesting finding in our study is that renal IgM deposition was positively correlated with both $\mathrm{pDC}$ and IFN- $\alpha$ abundance in IgAN patients. It was reported that renal IgM deposition was associated with disease progression or glomerular obsolescence in IgAN nephropathy [81, 82]. Besides, we found that renal IgM deposition was positively associated with proteinuria in IgAN patients (data not shown). Although TLR9 activation in pDC was related to IgM synthesis as described above, the underlying mechanism linking the pDC-IFN- $\alpha$ axis with renal IgM deposition in IgAN was still unknown.

IgA nephropathy was characterized with renal inflammation accompanied with leukocyte infiltration $[83,84]$. T cells and monocytes/macrophages were reported to be predominant infiltrated leukocytes in renal interstitial of IgAN patients, which was significantly correlated with histological injury and renal dysfunction [85-87]. Also, increased MCP1 expression was found in renal tissues of IgAN patients [88]. Here, we found that IFN- $\alpha$ strongly induces mRNA levels of IP-10 (CXCL10) and MCP-1 from mesangial cells in vitro and conditioned HMC supernatant with IFN- $\alpha$ pretreatment precipitates the transendothelial migration of $\mathrm{CD}_{1} 4^{+}$and $\mathrm{CD} 4^{+}$cells. Considering the fact that IP-10 and
MCP-1 were capable of promoting chemotaxis of peripheral blood monocytes and T cells [89-92], enhanced synthesis of IP-10 and MCP-1 from mesangial cells was pivotal in facilitating migration of leukocytes through endothelial cells in IgAN. Other than this, IFN- $\alpha$ stimulates the expression of its own receptor IFNAR1, which very possibly generates a positive feedback loop of IFN- $\alpha$ signaling. A recent study reported that endothelial cell injury was correlated with proteinuria, hematuria, and renal pathology in a rat IgAN model [93], indicating that integrity of endothelial cell was a key factor for renal function. Combined with our finding, these data support the hypothesis that hyperactivated pDC-IFN- $\alpha$ axis exerts strength on promoting the expression of chemokines, mediating leukocyte migration through endothelial cells into renal tissue, and causing proteinuria in IgA nephropathy.

In summary, our results revealed that the pDC-IFN- $\alpha$ axis was hyperactivated in patients of IgAN, which further promoted the differentiation of plasma cells and induction of chemokines for assisting migration of $\mathrm{T}$ cells and monocytes through endothelial cells. Our data illustrated, at least in part, the mechanism how pDC and IFN- $\alpha$ were involved in the pathogenesis of IgAN. As in lupus, high abundance of IFN $-\alpha$ and $\mathrm{pDC}$ leads to BCR response, B cell proliferation, and antibody production and subsequent proteinuria in lupus $[48,94-96]$. It is very possible that IFN- $\alpha$ plays a similar role in IgAN patients and lupus patients. Considering the fact that pDC-IFN- $\alpha$ blockade therapeutics including anti-IFN- $\alpha$ antibody, anti-IFNAR, pDC inhibitors, and TLR9 antagonist are in clinical trials with promising results in lupus $[97,98]$, controlling the pDC-IFN- $\alpha$ axis may also have a beneficial effect for the treatment of IgA nephropathy.

\section{Conflicts of Interest}

The authors declare that they have no competing interests.

\section{Acknowledgments}

This project was supported financially by the National Natural Science Foundation of China (31200664), the Young Researcher Foundation of Sun Yat-sen University, China (14YKPY17), and the Operation Funding for Key Laboratories of Guangdong Province (2014030301023). The authors really appreciated the help of Dr. Zhiqiang Huang from the University of Alabama (Birmingham, Alabama; USA) in manuscript preparation.

\section{Supplementary Materials}

Supplementary 1. Supplemental Figure 1: pDCs respond to CpG2216 stimulation and secrete large amount of IFN- $\alpha$ in PBMCs. Freshly isolated PBMCs from donors $(n=3)$ were stained with CD304-APC and CD123-FITC antibodies and subjected to cell sorting. Double positive cells were identified as pDC and the rest cells were identified as PBMCs no $\mathrm{pDC}(\mathrm{A})$. Secretion of IFN- $\alpha$ proteins in culture supernatant was detected by ELISA after CpG2216 stimulation for 24 hrs (B). 
Supplementary 2. Supplemental Figure 2: Synthesis of IFN- $\alpha$ induced by different types of oligodeoxynucleotides (ODN) in PBMCs. Freshly isolated PBMCs from donors $(n=3)$ were treated with different ODN as follows. ODN Ctrl: $5^{\prime}$ GGG ggagcatgctgCGGGGG3'; ODN 2216: 5'GGGggacgatcgtcGG GGGG3'; inhibitory ODN 1: 5'TCCTGGAGGGGTTGT3'; inhibitory ODN 2: $5^{\prime}$ TTTAGGGTTAGGGTTAGGGTTA GG G3'. (Nucleotides in upper letters correspond to phosphorothioate backbone). Culture supernatant was detected for IFN- $\alpha$ by ELISA after $24 \mathrm{hrs}$.

Supplementary 3. Supplemental Figure 3: The plasma cells differentiation in PBMCs was induced by CpG2216. Freshly isolated PBMCs from donors $(n=5)$ were subjected to vehicle or CpG2216 treatment for 6 days, followed by surface makers labeling and analysis in flow cytometry. (A) $\mathrm{CD} 19^{+}$ cells differentiated into plasma cells $\left(\mathrm{CD} 19^{+} \mathrm{CD} 38^{\mathrm{hi}} \mathrm{CD} 20^{\mathrm{lo}}\right)$ after Vehicle or CpG2216 stimulation for 6 days. (B) Comparison of plasma cell differentiation in Vehicle or $\mathrm{CpG}$ 2216-treated PBMCs from donors.

\section{References}

[1] J. Barratt and J. Feehally, "Primary IgA nephropathy: new insights into pathogenesis," Seminars in Nephrology, vol. 31, no. 4, pp. 349-360, 2011.

[2] R. Coppo, "The intestine-renal connection in IgA nephropathy," Nephrology, Dialysis, Transplantation, vol. 30, no. 3, pp. 360-366, 2015.

[3] K. Kiryluk and J. Novak, "The genetics and immunobiology of IgA nephropathy," The Journal of Clinical Investigation, vol. 124, no. 6, pp. 2325-2332, 2014.

[4] K. N. Lai, S. C. Tang, F. P. Schena et al., "IgA nephropathy," Nature Reviews Disease Primers, vol. 2, article 16001, 2016.

[5] A. A. Satoskar, G. Nadasdy, J. A. Plaza et al., "Staphylococcus infection-associated glomerulonephritis mimicking $\operatorname{IgA}$ nephropathy," Clinical Journal of the American Society of Nephrology, vol. 1, no. 6, pp. 1179-1186, 2006.

[6] C. Rollino, G. Vischini, and R. Coppo, "IgA nephropathy and infections," Journal of Nephrology, vol. 29, no. 4, pp. 463-468, 2016.

[7] H. Iwama, S. Horikoshi, I. Shirato, and Y. Tomino, "EpsteinBarr virus detection in kidney biopsy specimens correlates with glomerular mesangial injury," American Journal of Kidney Diseases, vol. 32, no. 5, pp. 785-793, 1998.

[8] Y. Kanno, H. Suzuki, H. Okada, Y. Nakazato, and T. Saruta, "Retroviral infection in peripheral mononuclear cells in patients with IgA nephropathy," Clinical Nephrology, vol. 47, no. 4, pp. 211-216, 1997.

[9] S. Akira and K. Takeda, "Toll-like receptor signalling," Nature Reviews Immunology, vol. 4, no. 7, pp. 499-511, 2004.

[10] T. Kawai and S. Akira, "Toll-like receptors and their crosstalk with other innate receptors in infection and immunity," Immunity, vol. 34, no. 5, pp. 637-650, 2011.

[11] T. Kawai and S. Akira, "The role of pattern-recognition receptors in innate immunity: update on Toll-like receptors," Nature Immunology, vol. 11, no. 5, pp. 373-384, 2010.

[12] W. P. Pulskens, G. J. Teske, L. M. Butter et al., “Toll-like receptor-4 coordinates the innate immune response of the kidney to renal ischemia/reperfusion injury," PLoS One, vol. 3, no. 10, article e3596, 2008.
[13] S. Ceccarelli, V. Nobili, and A. Alisi, "Toll-like receptormediated signaling cascade as a regulator of the inflammation network during alcoholic liver disease," World Journal of Gastroenterology, vol. 20, no. 44, pp. 16443-16451, 2014.

[14] E. D. Papadimitraki, G. K. Bertsias, and D. T. Boumpas, “Toll like receptors and autoimmunity: a critical appraisal," Journal of Autoimmunity, vol. 29, no. 4, pp. 310-318, 2007.

[15] M. Colonna, "Toll-like receptors and IFN- $\alpha$ : partners in autoimmunity," The Journal of Clinical Investigation, vol. 116, no. 9, pp. 2319-2322, 2006.

[16] R. Coppo, R. Camilla, A. Amore et al., "Toll-like receptor 4 expression is increased in circulating mononuclear cells of patients with immunoglobulin A nephropathy," Clinical and Experimental Immunology, vol. 159, no. 1, pp. 73-81, 2010.

[17] M. E. Donadio, E. Loiacono, L. Peruzzi et al., “Toll-like receptors, immunoproteasome and regulatory $\mathrm{T}$ cells in children with Henoch-Schönlein purpura and primary IgA nephropathy," Pediatric Nephrology, vol. 29, no. 9, pp. 1545-1551, 2014.

[18] H. Suzuki, Y. Suzuki, I. Narita et al., "Toll-like receptor 9 affects severity of IgA nephropathy," Journal of the American Society of Nephrology, vol. 19, no. 12, pp. 2384-2395, 2008.

[19] T. Kajiyama, Y. Suzuki, M. Kihara, H. Suzuki, S. Horikoshi, and Y. Tomino, "Different pathological roles of toll-like receptor 9 on mucosal $\mathrm{B}$ cells and dendritic cells in murine IgA nephropathy," Clinical and Developmental Immunology, vol. 2011, Article ID 819646, 10 pages, 2011.

[20] D. Sato, Y. Suzuki, T. Kano et al., "Tonsillar TLR9 expression and efficacy of tonsillectomy with steroid pulse therapy in IgA nephropathy patients," Nephrology, Dialysis, Transplantation, vol. 27, no. 3, pp. 1090-1097, 2012.

[21] B. Reizis, A. Bunin, H. S. Ghosh, K. L. Lewis, and V. Sisirak, "Plasmacytoid dendritic cells: recent progress and open questions," Annual Review of Immunology, vol. 29, no. 1, pp. 163-183, 2011.

[22] T. Ito, M. Inaba, K. Inaba et al., "A CD1a ${ }^{+} / \mathrm{CD} 11 c^{+}$subset of human blood dendritic cells is a direct precursor of Langerhans cells," The Journal of Immunology, vol. 163, pp. 1409-1419, 1999.

[23] N. Kohrgruber, N. Halanek, M. Groger et al., "Survival, maturation, and function of $\mathrm{CD} 11 \mathrm{c}^{-}$and $\mathrm{CD} 11 \mathrm{c}^{+}$peripheral blood dendritic cells are differentially regulated by cytokines," The Journal of Immunology, vol. 163, pp. 3250-3259, 1999.

[24] J. Olweus, A. Bitmansour, R. Warnke et al., "Dendritic cell ontogeny: a human dendritic cell lineage of myeloid origin," Proceedings of the National Academy of Sciences of the United States of America, vol. 94, no. 23, pp. 12551-12556, 1997.

[25] M. R. Comeau, A. R. Van der Vuurst de Vries, C. R. Maliszewski, and L. Galibert, "CD123 ${ }^{\text {bright }}$ plasmacytoid predendritic cells: progenitors undergoing cell fate conversion?," The Journal of Immunology, vol. 169, no. 1, pp. 75-83, 2002.

[26] A. Dzionek, Y. Inagaki, K. Okawa et al., "Plasmacytoid dendritic cells: from specific surface markers to specific cellular functions," Human Immunology, vol. 63, no. 12, pp. 11331148, 2002.

[27] J. Chehimi, S. E. Starr, H. Kawashima et al., "Dendritic cells and IFN- $\alpha$-producing cells are two functionally distinct non$\mathrm{B}$, non-monocytic HLA-DR ${ }^{+}$cell subsets in human peripheral blood," Immunology, vol. 68, no. 4, pp. 486-490, 1989.

[28] F. P. Siegal, N. Kadowaki, M. Shodell et al., "The nature of the principal type 1 interferon-producing cells in human blood," Science, vol. 284, no. 5421, pp. 1835-1837, 1999. 
[29] K. B. Elkon and D. M. Santer, "Complement, interferon and lupus," Current Opinion in Immunology, vol. 24, no. 6, pp. 665-670, 2012.

[30] N. Kadowaki, S. Ho, S. Antonenko et al., "Subsets of human dendritic cell precursors express different toll-like receptors and respond to different microbial antigens," The Journal of Experimental Medicine, vol. 194, no. 6, pp. 863-870, 2001.

[31] Y. J. Liu, "IPC: professional type 1 interferon-producing cells and plasmacytoid dendritic cell precursors," Annual Review of Immunology, vol. 23, no. 1, pp. 275-306, 2005.

[32] K. Honda, Y. Ohba, H. Yanai et al., "Spatiotemporal regulation of MyD88-IRF-7 signalling for robust type-I interferon induction," Nature, vol. 434, no. 7036, pp. 1035-1040, 2005.

[33] C. Guiducci, G. Ott, J. H. Chan et al., "Properties regulating the nature of the plasmacytoid dendritic cell response to Toll-like receptor 9 activation," The Journal of Experimental Medicine, vol. 203, no. 8, pp. 1999-2008, 2006.

[34] A. Krug, S. Rothenfusser, V. Hornung et al., "Identification of $\mathrm{CpG}$ oligonucleotide sequences with high induction of IFN- $\alpha / \beta$ in plasmacytoid dendritic cells," European Journal of Immunology, vol. 31, no. 7, pp. 2154-2163, 2001.

[35] A. M. Krieg, "CpG motifs in bacterial DNA and their immune effects," Annual Review of Immunology, vol. 20, no. 1, pp. 709$760,2002$.

[36] G. Hartmann, J. Battiany, H. Poeck et al., "Rational design of new CpG oligonucleotides that combine B cell activation with high IFN- $\alpha$ induction in plasmacytoid dendritic cells," European Journal of Immunology, vol. 33, no. 6, pp. 16331641, 2003.

[37] A. M. Krieg, A. K. Yi, S. Matson et al., "CpG motifs in bacterial DNA trigger direct B-cell activation," Nature, vol. 374, no. 6522, pp. 546-549, 1995.

[38] A Working Group of the International IgA Nephropathy Network and the Renal Pathology Society Group, D. C. Cattran, R. Coppo et al., "The Oxford classification of IgA nephropathy: rationale, clinicopathological correlations, and classification," Kidney International, vol. 76, no. 5, pp. 534545, 2009.

[39] H. Kataoka, M. Ohara, K. Shibui et al., "Overweight and obesity accelerate the progression of IgA nephropathy: prognostic utility of a combination of BMI and histopathological parameters," Clinical and Experimental Nephrology, vol. 16, no. 5, pp. 706-712, 2012.

[40] S. H. Kang, S. R. Choi, H. S. Park et al., "The Oxford classification as a predictor of prognosis in patients with IgA nephropathy," Nephrology, Dialysis, Transplantation, vol. 27, no. 1, pp. 252-258, 2012.

[41] I. Douagi, C. Gujer, C. Sundling et al., "Human B cell responses to TLR ligands are differentially modulated by myeloid and plasmacytoid dendritic cells," The Journal of Immunology, vol. 182, no. 4, pp. 1991-2001, 2009.

[42] F. He, F. Peng, X. Xia et al., "MiR-135a promotes renal fibrosis in diabetic nephropathy by regulating TRPC1," Diabetologia, vol. 57, no. 8, pp. 1726-1736, 2014.

[43] K. J. Livak and T. D. Schmittgen, "Analysis of Relative Gene Expression Data Using Real-Time Quantitative PCR and the $2^{-\Delta \Delta C}$ Tethod," Methods, vol. 25, no. 4, pp. 402-408, 2001.

[44] P. Pietschmann, J. J. Cush, P. E. Lipsky, and N. OppenheimerMarks, "Identification of subsets of human T cells capable of enhanced transendothelial migration," The Journal of Immunology, vol. 149, pp. 1170-1178, 1992.
[45] C. M. Sun, E. Deriaud, C. Leclerc, and R. Lo-Man, "Upon TLR9 signaling, $\mathrm{CD}^{+} \mathrm{B}$ cells control the IL-12-dependent Th1-priming capacity of neonatal DCs," Immunity, vol. 22, no. 4, pp. 467-477, 2005.

[46] R. Lande, J. Gregorio, V. Facchinetti et al., "Plasmacytoid dendritic cells sense self-DNA coupled with antimicrobial peptide," Nature, vol. 449, no. 7162, pp. 564-569, 2007.

[47] F. H. Wikstrom, C. Fossum, L. Fuxler, R. Kruse, and T. Lovgren, "Cytokine induction by immunostimulatory DNA in porcine PBMC is impaired by a hairpin forming sequence motif from the genome of Porcine circovirus type 2 (PCV2)," Veterinary Immunology and Immunopathology, vol. 139, no. 2-4, pp. 156-166, 2011.

[48] L. Ronnblom, G. V. Alm, and M. L. Eloranta, “Type I interferon and lupus," Current Opinion in Rheumatology, vol. 21, no. 5, pp. 471-477, 2009.

[49] F. O. Nestle, C. Conrad, A. Tun-Kyi et al., "Plasmacytoid predendritic cells initiate psoriasis through interferon- $\alpha$ production," The Journal of Experimental Medicine, vol. 202, no. 1, pp. 135-143, 2005.

[50] M. Gilliet, W. Cao, and Y. J. Liu, "Plasmacytoid dendritic cells: sensing nucleic acids in viral infection and autoimmune diseases," Nature Reviews Immunology, vol. 8, no. 8, pp. 594606, 2008.

[51] J. J. Hooks, H. M. Moutsopoulos, S. A. Geis, N. I. Stahl, J. L. Decker, and A. L. Notkins, "Immune interferon in the circulation of patients with autoimmune disease," The New England Journal of Medicine, vol. 301, no. 1, pp. 5-8, 1979.

[52] L. Farkas, K. Beiske, F. Lund-Johansen, P. Brandtzaeg, and F. L. Jahnsen, "Plasmacytoid dendritic cells (natural interferon- $\alpha / \beta$-producing cells) accumulate in cutaneous lupus erythematosus lesions," The American Journal of Pathology, vol. 159, no. 1, pp. 237-243, 2001.

[53] T. B. Niewold, J. Hua, T. J. Lehman, J. B. Harley, and M. K. Crow, "High serum IFN- $\alpha$ activity is a heritable risk factor for systemic lupus erythematosus," Genes and Immunity, vol. 8, no. 6, pp. 492-502, 2007.

[54] L. Bennett, A. K. Palucka, E. Arce et al., "Interferon and granulopoiesis signatures in systemic lupus erythematosus blood," The Journal of Experimental Medicine, vol. 197, no. 6, pp. 711723, 2003.

[55] E. I. Lichtman, S. M. Helfgott, and M. A. Kriegel, "Emerging therapies for systemic lupus erythematosu-focus on targeting interferon-alpha," Clinical Immunology, vol. 143, no. 3, pp. 210-221, 2012.

[56] D. L. Thibault, K. L. Graham, L. Y. Lee, I. Balboni, P. J. Hertzog, and P. J. Utz, "Type I interferon receptor controls B-cell expression of nucleic acid-sensing Toll-like receptors and autoantibody production in a murine model of lupus," Arthritis Research \& Therapy, vol. 11, no. 4, article R112, 2009.

[57] G. Galicia and J. L. Gommerman, "Plasmacytoid dendritic cells and autoimmune inflammation," Biological Chemistry, vol. 395, no. 3, pp. 335-346, 2014.

[58] T. Ito, Y. H. Wang, and Y. J. Liu, "Plasmacytoid dendritic cell precursors/type I interferon-producing cells sense viral infection by Toll-like receptor (TLR) 7 and TLR9," Springer Seminars in Immunopathology, vol. 26, no. 3, pp. 221-229, 2005.

[59] M. Muto, B. Manfroi, H. Suzuki et al., "Toll-like receptor 9 stimulation induces aberrant expression of a proliferationinducing ligand by tonsillar germinal center B cells in IgA 
nephropathy," Journal of the American Society of Nephrology, vol. 28 , no. 4, pp. 1227-1238, 2016.

[60] P. S. Jahn, K. S. Zanker, J. Schmitz, and A. Dzionek, "BDCA-2 signaling inhibits TLR-9-agonist-induced plasmacytoid dendritic cell activation and antigen presentation," Cellular Immunology, vol. 265, no. 1, pp. 15-22, 2010.

[61] G. Gerlini, C. Urso, G. Mariotti et al., "Plasmacytoid dendritic cells represent a major dendritic cell subset in sentinel lymph nodes of melanoma patients and accumulate in metastatic nodes," Clinical Immunology, vol. 125, no. 2, pp. 184-193, 2007.

[62] S. Bezalel, K. M. Guri, D. Elbirt, I. Asher, and Z. M. Sthoeger, "Type I interferon signature in systemic lupus erythematosus," The Israel Medical Association Journal, vol. 16, no. 4, pp. 246249, 2014.

[63] L. Giordani, M. Sanchez, I. Libri, M. G. Quaranta, B. Mattioli, and M. Viora, "IFN- $\alpha$ amplifies human naïve B cell TLR-9mediated activation and Ig production," Journal of Leukocyte Biology, vol. 86, no. 2, pp. 261-271, 2009.

[64] D. Tarlinton, A. Radbruch, F. Hiepe, and T. Dorner, "Plasma cell differentiation and survival," Current Opinion in Immunology, vol. 20, no. 2, pp. 162-169, 2008.

[65] M. I. Vazquez, J. Catalan-Dibene, and A. Zlotnik, "B cells responses and cytokine production are regulated by their immune microenvironment," Cytokine, vol. 74, no. 2, pp. 318-326, 2015.

[66] D. Braun, I. Caramalho, and J. Demengeot, "IFN- $\alpha / \beta$ enhances BCR-dependent B cell responses," International Immunology, vol. 14, no. 4, pp. 411-419, 2002.

[67] C. Gujer, K. J. Sandgren, I. Douagi et al., "IFN- $\alpha$ produced by human plasmacytoid dendritic cells enhances $\mathrm{T}$ celldependent naïve B cell differentiation," Journal of Leukocyte Biology, vol. 89, no. 6, pp. 811-821, 2011.

[68] S. J. Harper, A. C. Allen, J. H. Pringle, and J. Feehally, "Increased dimeric IgA producing B cells in the bone marrow in IgA nephropathy determined by in situ hybridisation for J chain mRNA," Journal of Clinical Pathology, vol. 49, no. 1, pp. 38-42, 1996.

[69] R. A. Manz, A. Thiel, and A. Radbruch, "Lifetime of plasma cells in the bone marrow," Nature, vol. 388, no. 6638, pp. 133-134, 1997.

[70] E. Zhao, H. Xu, L. Wang et al., "Bone marrow and the control of immunity," Cellular \& Molecular Immunology, vol. 9, pp. 11-19, 2012.

[71] F. Hiepe and A. Radbruch, "Plasma cells as an innovative target in autoimmune disease with renal manifestations," Nature Reviews Nephrology, vol. 12, no. 4, pp. 232-240, 2016.

[72] C. Dai, H. Wang, S. S. Sung et al., "Interferon alpha on NZM2328.Lc1R27: enhancing autoimmunity and immune complex-mediated glomerulonephritis without end stage renal failure," Clinical Immunology, vol. 154, no. 1, pp. 66-71, 2014.

[73] A. Mathian, A. Weinberg, M. Gallegos, J. Banchereau, and S. Koutouzov, "IFN- $\alpha$ induces early lethal lupus in preautoimmune (New Zealand Black $\times$ New Zealand White) $\mathrm{F}_{1}$ but not in BALB/c mice," The Journal of Immunology, vol. 174, no. 5, pp. 2499-2506, 2005.

[74] A. M. Fairhurst, A. Mathian, J. E. Connolly et al., "Systemic IFN- $\alpha$ drives kidney nephritis in B6.Sle123 mice," European Journal of Immunology, vol. 38, no. 7, pp. 1948-1960, 2008.

[75] G. Jego, A. K. Palucka, J. P. Blanck, C. Chalouni, V. Pascual, and J. Banchereau, "Plasmacytoid dendritic cells induce plasma cell differentiation through type I interferon and interleukin 6," Immunity, vol. 19, no. 2, pp. 225-234, 2003.

[76] C. Ding, Y. Cai, J. Marroquin, S. T. Ildstad, and J. Yan, "Plasmacytoid dendritic cells regulate autoreactive B cell activation via soluble factors and in a cell-to-cell contact manner," The Journal of Immunology, vol. 183, no. 11, pp. 7140-7149, 2009.

[77] L. H. Tai, M. L. Goulet, S. Belanger et al., "Positive regulation of plasmacytoid dendritic cell function via Ly49Q recognition of class I MHC," The Journal of Experimental Medicine, vol. 205, no. 13, pp. 3187-3199, 2008.

[78] H. Tezuka, Y. Abe, J. Asano et al., "Prominent role for plasmacytoid dendritic cells in mucosal $\mathrm{T}$ cell-independent IgA induction," Immunity, vol. 34, no. 2, pp. 247-257, 2011.

[79] M. Jourdan, M. Cren, N. Robert et al., "IL-6 supports the generation of human long-lived plasma cells in combination with either APRIL or stromal cell-soluble factors," Leukemia, vol. 28, no. 8, pp. 1647-1656, 2014.

[80] H. Poeck, M. Wagner, J. Battiany et al., "Plasmacytoid dendritic cells, antigen, and CpG-C license human B cells for plasma cell differentiation and immunoglobulin production in the absence of T-cell help," Blood, vol. 103, no. 8, pp. 3058-3064, 2004.

[81] Z. Liu and L. Li, "Significance of IgM deposition in IgA nephropathy: an appraisal based on renal re-biopsy," Zhonghua Yi Xue Za Zhi, vol. 70, no. 6, pp. 324-326, 1990.

[82] T. Moriyama, A. Shimizu, T. Takei, K. Uchida, K. Honda, and K. Nitta, "Characteristics of immunoglobulin A nephropathy with mesangial immunoglobulin $\mathrm{G}$ and immunoglobulin $\mathrm{M}$ deposition," Nephrology, vol. 15, no. 8, pp. 747-754, 2010.

[83] T. Ootaka, T. Saito, J. Soma, A. Yusa, and K. Abe, "Mechanism of infiltration and activation of glomemlar monocytes/macrophages in IgA nephropathy," American Journal of Nephrology, vol. 17, no. 2, pp. 137-145, 1997.

[84] Y. Tomino, "Pathogenesis of IgA nephropathy," Contributions to Nephrology, vol. 157, pp. 1-7, 2007.

[85] T. Ootaka, T. Saito, A. Yusa, T. Munakata, J. Soma, and K. Abe, "Contribution of cellular infiltration to the progression of IgA nephropathy: a longitudinal, immunocytochemical study on repeated renal biopsy specimens," Nephrology, vol. 1, no. 2, pp. 135-142, 1995.

[86] W. M. Danilewicz and M. Danilewicz, "Renal interstitial enascin immunostaining and immune cell infiltration in $\operatorname{IgA}$ nephropathy," Nephrology, vol. 6, no. 3, pp. 127-131, 2001.

[87] G. E. Silva, R. S. Costa, R. C. Ravinal et al., "Renal macrophage infiltration is associated with a poor outcome in IgA nephropathy," Clinics, vol. 67, no. 7, pp. 697-703, 2012.

[88] Z. Shuiai, S. Huijun, G. Weizhong, L. Aimin, and M. Jianhua, "Evaluation of TGF- $\beta 1$ and MCP-1 expression and tubulointerstitial fibrosis in children with Henoch-Schönlein purpura nephritis and IgA nephropathy: a clinical correlation," Clinics, vol. 72, no. 2, pp. 95-102, 2017.

[89] D. D. Taub, A. R. Lloyd, K. Conlon et al., "Recombinant human interferon-inducible protein 10 is a chemoattractant for human monocytes and T lymphocytes and promotes $\mathrm{T}$ cell adhesion to endothelial cells," The Journal of Experimental Medicine, vol. 177, no. 6, pp. 1809-1814, 1993.

[90] I. F. Charo and R. M. Ransohoff, "The many roles of chemokines and chemokine receptors in inflammation," The New England Journal of Medicine, vol. 354, no. 6, pp. 610$621,2006$. 
[91] J. P. Cai, S. Hudson, M. W. Ye, and Y. H. Chin, "The intracellular signaling pathways involved in MCP-1-stimulated T cell migration across microvascular endothelium," Cellular Immunology, vol. 167, no. 2, pp. 269-275, 1996.

[92] R. Pai, H. Ha, M. A. Kirschenbaum, and V. S. Kamanna, "Role of tumor necrosis factor- $\alpha$ on mesangial cell MCP-1 expression and monocyte migration: mechanisms mediated by signal transduction," Journal of the American Society of Nephrology, vol. 7, no. 6, pp. 914-923, 1996.

[93] T. Kusano, H. Takano, D. Kang et al., "Endothelial cell injury in acute and chronic glomerular lesions in patients with IgA nephropathy," Human Pathology, vol. 49, pp. 135-144, 2016.

[94] N. H. Chang, T. T. Li, J. J. Kim et al., "Interferon- $\alpha$ induces altered transitional B cell signaling and function in systemic lupus erythematosus," Journal of Autoimmunity, vol. 58, pp. 100-110, 2015.

[95] A. Mathian, M. Gallegos, V. Pascual, J. Banchereau, and S. Koutouzov, "Interferon- $\alpha$ induces unabated production of short-lived plasma cells in pre-autoimmune lupus-prone $(\mathrm{NZB} \times \mathrm{NZW}) \mathrm{F} 1$ mice but not in BALB/c mice," European Journal of Immunology, vol. 41, no. 3, pp. 863-872, 2011.

[96] Z. Liu, R. Bethunaickan, W. Huang et al., "Interferon- $\alpha$ accelerates murine systemic lupus erythematosus in a T celldependent manner," Arthritis and Rheumatism, vol. 63, no. 1, pp. 219-229, 2011.

[97] K. A. Kirou and E. Gkrouzman, "Anti-interferon alpha treatment in SLE," Clinical Immunology, vol. 148, no. 3, pp. 303-312, 2013.

[98] R. Furie, M. Khamashta, J. T. Merrill et al., "Anifrolumab, an anti-interferon- $\alpha$ receptor monoclonal antibody, in moderate-to-severe systemic lupus erythematosus," Arthritis \& Rhematology, vol. 69, no. 2, pp. 376-386, 2017. 


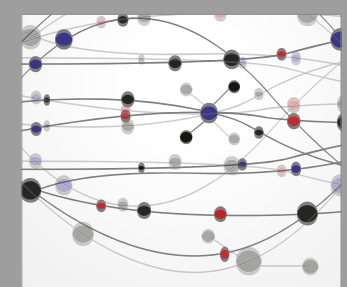

The Scientific World Journal
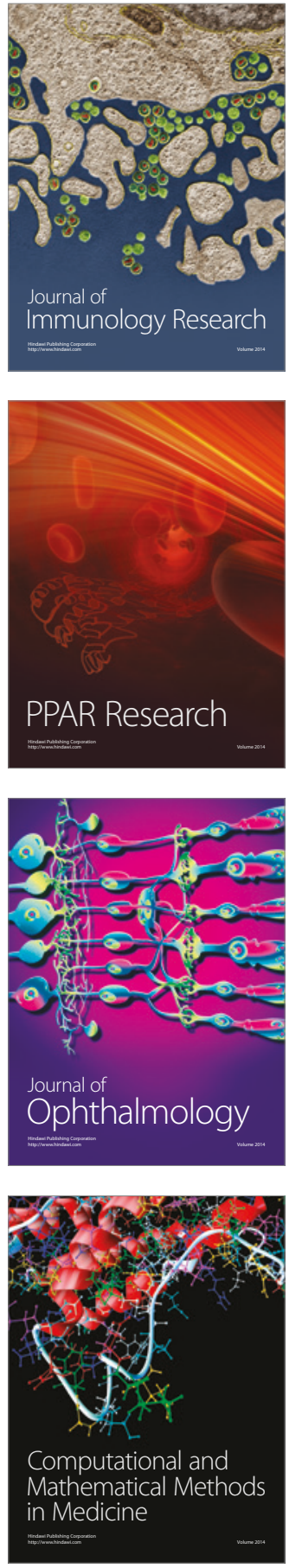

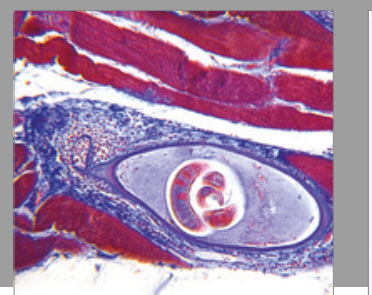

Gastroenterology Research and Practice
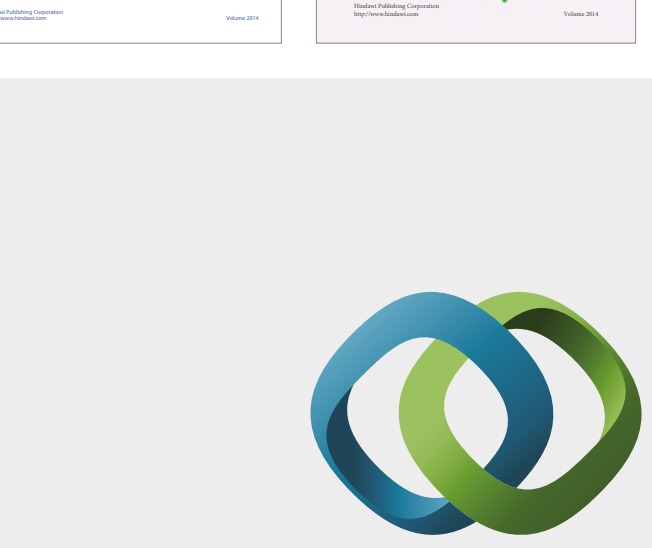

\section{Hindawi}

Submit your manuscripts at

https://www.hindawi.com
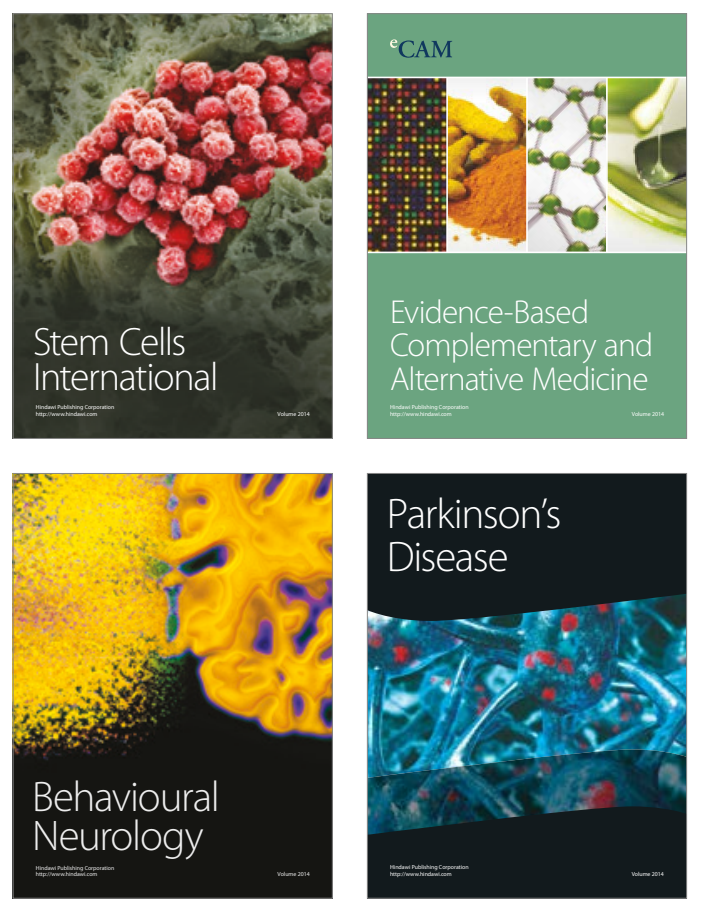
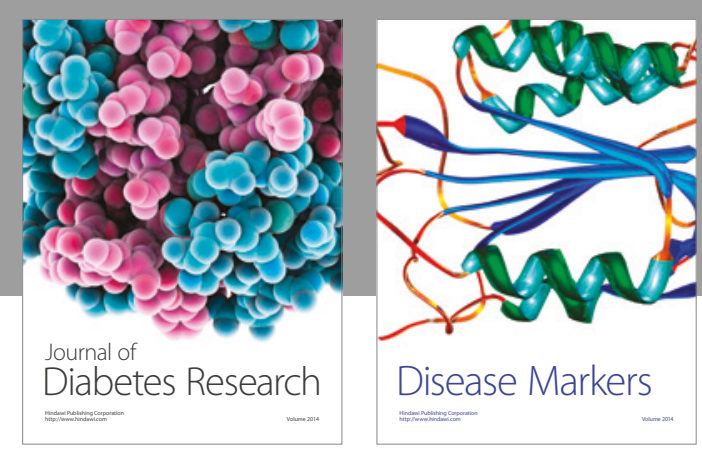

Disease Markers
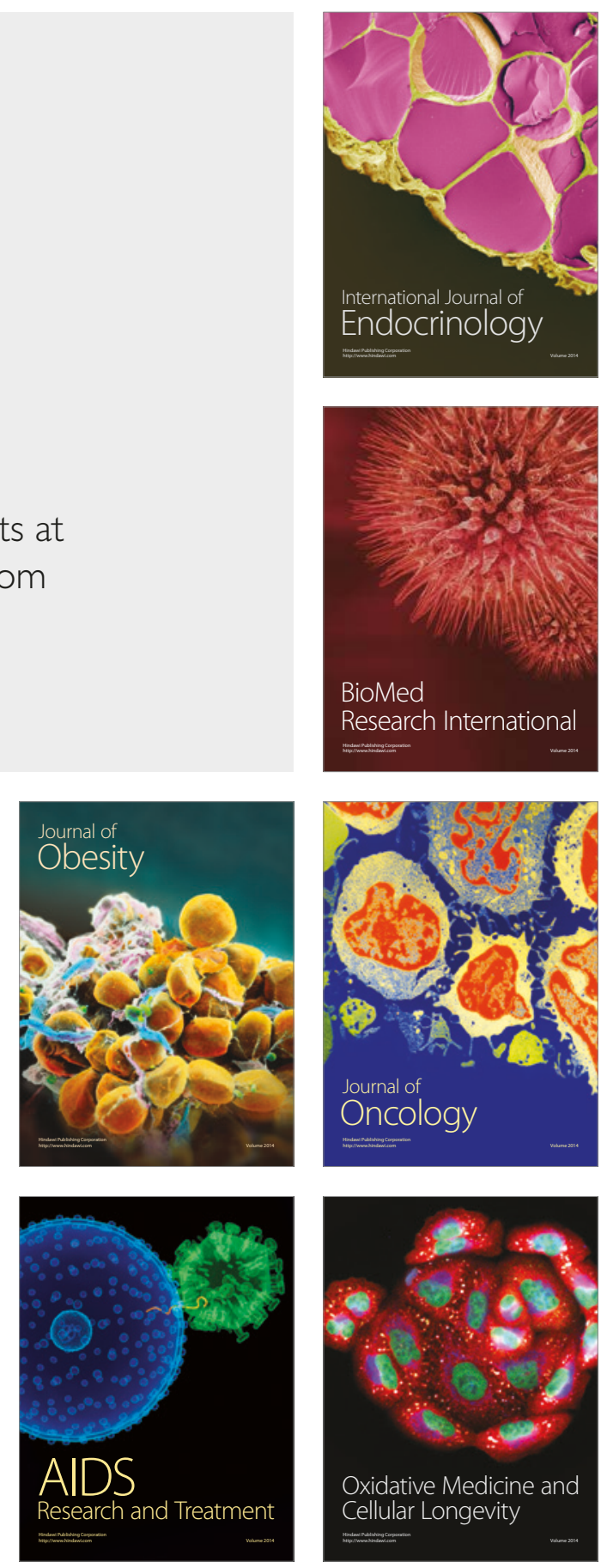